\title{
Interleukin gene polymorphisms and breast cancer: a case control study and systematic literature review SP Balasubramanian*1, IAF Azmy ${ }^{1}$, SE Higham¹, AG Wilson², SS Cross ${ }^{3}$, A Cox ${ }^{4}$, NJ Brown ${ }^{1}$ and MW Reed ${ }^{1}$
}

\author{
Address: ${ }^{1}$ Academic Surgical Oncology Unit, University of Sheffield, Sheffield, UK, ${ }^{2}$ Academic Rheumatology Unit, University of Sheffield, \\ Sheffield, UK, ${ }^{3}$ Academic Unit of Pathology, University of Sheffield, Sheffield, UK and ${ }^{4}$ Institute of Cancer Studies, University of Sheffield, \\ Sheffield, UK \\ Email: SP Balasubramanian* - s.p.balasubramanian@sheffield.ac.uk; IAF Azmy - i.azmy@doctors.net.uk; SE Higham - s.e.higham@shef.ac.uk; \\ AG Wilson - a.g.wilson@shef.ac.uk; SS Cross - s.s.cross@shef.ac.uk; A Cox - a.cox@shef.ac.uk; NJ Brown - n.j.brown@shef.ac.uk; \\ MW Reed - m.w.reed@shef.ac.uk \\ * Corresponding author
}

Published: 14 July 2006

BMC Cancer 2006, 6:188 doi:10.1 |86/147|-2407-6-188
Received: 23 January 2006

Accepted: 14 July 2006

This article is available from: http://www.biomedcentral.com//47/-2407/6//88

(c) 2006 Balasubramanian et al; licensee BioMed Central Ltd.

This is an Open Access article distributed under the terms of the Creative Commons Attribution License (http://creativecommons.org/licenses/by/2.0), which permits unrestricted use, distribution, and reproduction in any medium, provided the original work is properly cited.

\begin{abstract}
Background: Interleukins and cytokines play an important role in the pathogenesis of many solid cancers. Several single nucleotide polymorphisms (SNPs) identified in cytokine genes are thought to influence the expression or function of these proteins and many have been evaluated for their role in inflammatory disease and cancer predisposition. The aim of this study was to evaluate any role of specific SNPs in the interleukin genes ILIA, ILIB, ILIRN, IL4R, IL6 and ILI 0 in predisposition to breast cancer susceptibility and severity.
\end{abstract}

Methods: Candidate single nucleotide polymorphisms (SNPs) in key cytokine genes were genotyped in breast cancer patients and in appropriate healthy volunteers who were similar in age, race and sex. Genotyping was performed using a high throughput allelic discrimination method. Data on clinico-pathological details and survival were collected. A systematic review of Medline English literature was done to retrieve previous studies of these polymorphisms in breast cancer.

Results: None of the polymorphisms studied showed any overall predisposition to breast cancer susceptibility, severity or to time to death or occurrence of distant metastases. The results of the systematic review are summarised.

Conclusion: Polymorphisms within key interleukin genes (ILIA, ILIB, ILIRN, IL4R, IL6 and ILI0 do not appear to play a significant overall role in breast cancer susceptibility or severity.

\section{Background}

The role of cytokines in cancer immunity and carcinogenesis in general has been well established [1]. Single nucleotide polymorphisms in specific candidate genes are thought to influence expression and/or activity of the encoding proteins thereby predisposing to solid cancers especially breast cancer [2]. Many cytokine polymorphisms have been studied for associations with susceptibility to gastric cancer [3-5], liver cancer [6,7], lung cancer[8], prostate cancer [9] and ovarian cancer [10] with mixed results. 
The cytokines of the IL-1 family [11], IL-4 and its receptor $[12,13]$, IL-6 [14,15] and IL-10 [16,17] are important candidate genes as they play an important role in breast cancer pathogenesis. IL1-alpha promotes growth of breast cancer cells and cachexia [18]. In breast cancer cells, IL1beta increases the transcriptional activity of ER-alpha [19] which is a prognostic factor in breast cancer and the expression and stabilisation of IL-8 RNA [20] which is a potent angiogenic factor. IL-4 inhibits tumour growth by its anti-angiogenic effect [21] and inhibits growth and induces apoptosis of breast cancer cell lines in the presence of IL-4R [12]. Circulating IL6 levels have been found to be higher in breast cancer patients compared to healthy controls and among those with breast cancer, correlate with the stage of the disease [14]. IL10 is over expressed in breast tumours [16] and exogenous administration can mediate regression of tumour growth and breast cancer metastases in mice models [17].

The polymorphisms studied were selected in the light of previous reports of their effect on differential gene expression and/or disease susceptibility. The IL1A +4845 G>T polymorphism situated in exon 5 of the IL1A gene was described in 1993 [22] and results in an Ala to Ser amino acid substitution at residue 114 of the prolL1 $\alpha$ molecule. Pro IL1 $\alpha$ is cleaved between amino acids 112 and 113 and it has been suggested that this polymorphism may affect the proteolytic process [23]. The polymorphism is thought to influence $\mathrm{C}$ reactive protein levels in patients referred for coronary angiography [24] and influence the development of aggressive periodontitis in Chinese males [25]. Three polymorphisms commonly studied in the IL1B gene include -511 and -31 in the promoter region and the +3954 in exon 5 , all representing a $\mathrm{C}>\mathrm{T}$ single nucleotide change. The $-511 \mathrm{C}>\mathrm{T}$ and the $+3954 \mathrm{C}>\mathrm{T}$ SNPs are thought to influence $\mathrm{C}$ reactive protein levels in healthy individuals [26] and the $+3954 \mathrm{C}>\mathrm{T}$ polymorphism has been shown to influence IL1 $\beta$ production by monocytes in vitro [27]. The -511 polymorphism has been shown to be associated with vascular diseases such as stroke [28] and along with the +3954 polymorphisms has been extensively studied in gastric cancer [29-31]. The IL1RN +2018T>C polymorphism in exon 2 of the gene is in complete linkage disequilibrium with a penta-allelic 86 bp variable number of tandem repeat polymorphism in intron 2 of the gene which is strongly linked to increased production of IL1RA [32] and IL1 $\beta$ in vitro [33]. The penta-allelic polymorphism has been studied in several cancers including gastric cancer [29-31], lung cancer [34], ovarian cancer [35] and cervical cancer [36]. The +2018 SNP itself has been linked with Barrett's oesophagus and oesophageal cancer [37]. The IL4R 1902A>G polymorphism is an A to $\mathrm{G}$ transition at nucleotide 1902, causing a change in amino acid from glutamine to arginine at codon 576 in the interleukin-4 receptor alpha protein.
This seems to alter the signalling function of the receptor, thereby predisposing carriers to disease [38]. Preliminary studies show some association of this polymorphism with Crohn's disease [39] and adult asthma [40]. The polymorphism has also been associated with an increased risk of renal cancer [41]. The IL6 -174G $>$ C polymorphism in the 5 ' flanking region of the gene was initially reported in 1998 to influence IL6 expression and plasma levels (the $174 \mathrm{C}$ allele associated with lower expression and lower levels) [42]. Subsequent studies of this polymorphism show that the $-174 \mathrm{C}$ allele decreases susceptibility to systemic juvenile idiopathic arthritis [43] and increases the risk of coronary artery disease presumably through inflammatory mechanisms [44,45]. It also has been shown to increase the risk of bladder cancer [46], colorectal cancer [47] and Kaposi's sarcoma in HIV infected men [48]. The IL10 -1082G>A polymorphism, situated in the promoter region of the gene, has been shown to influence IL10 protein production in vitro by concanavalin-A stimulated peripheral mononuclear cells [49]. The G allele is associated with an increased risk of Crohn's disease [50] and thought to increase predisposition to lung cancer [51]. The AA genotype has been shown to be associated with decreased survival in melanoma [52].

The aim of this study was to evaluate polymorphisms in specific cytokine genes [IL1A +4845G>T, IL1B -511C>T, IL1B + 3954C>T, IL1RN +2018T>C, IL4R -1902A>G, IL6$174 \mathrm{G}>\mathrm{C}$ and IL10-1082G $>\mathrm{A}$ ] in a case control model to determine any associations with breast cancer susceptibility, severity and survival. A systematic review of the English language Medline literature through PubMed was performed to summarise all previous breast cancer related studies of the polymorphisms characterised in the current study.

\section{Methods \\ Case-control study}

The design and methodology of this case control study have previously been described [53,54]. Briefly, recruitment started in November 1998 and is ongoing. The cases include women diagnosed with breast cancer and being followed up at the Royal Hallamshire Hospital in Sheffield and Rotherham District General Hospital and controls were recruited from women attending the Sheffield Breast Screening Service. The study was restricted to white Caucasians, as there were insufficient individuals from other ethnic groups, for meaningful analysis. The South Sheffield Research Ethics Committee approved the study [Ref. no. SS98/137] and informed written consent was obtained from all subjects. Demographic, environmental risk factors and family history data were recorded for all breast cancer cases and mammography screening controls, using a standard questionnaire. Pathological data (including tumour grade, lymph node status and presence 
of vascular invasion) were obtained from medical records and validated by an experienced histopathologist (SSC). Data on disease recurrence and overall survival were obtained from the hospital records and the Trent Cancer Registry. The data was entered by trained personnel and stored in a Microsoft Access database and maintained by a dedicated database administrator. The data was validated for all the records (by SPB and database manager).

\section{Genotyping methods}

Genomic DNA was extracted from frozen EDTA preserved peripheral venous blood from all individuals, as described previously [55]. The polymorphisms studied, along with the genes, location and unique ID is shown in Table 1. Genotyping of the polymorphisms was performed by the 5'nuclease PCR method, using the ABI/PE Biosystems Taqman ${ }^{\mathrm{TM}}$ system, essentially as described earlier [55]. Using specific primer and probe sequences (Table 1), PCR amplification was carried out separately for the different polymorphisms. The final concentrations of the different constituents of the PCR mixture and the cycling temperatures for the various SNPs studied are shown in Tables 2 and 3. Levels of FAM and TET fluorescence were determined and allelic discrimination was carried out using the ABI 7200 Sequence Detector. Quality control for the genotyping results was achieved by using only 72 of the 96 wells in each of the plates for the individual DNA samples subjected to PCR. Six to eight wells were allotted to 'no sample' controls, 'common homozygous' controls and 'rare homozygous' controls each, in addition to retesting of samples with indeterminate results. The common and rare homozygous controls included samples tested before and shown to be 'common homozygous' and 'rare homozygous' respectively.

\section{Methodology for systematic review}

A Medline search was conducted on 26 th September 2005 with the following search strategy: ( "interleukins"[TIAB] NOT Medline [SB]) OR "interleukins"[MeSH Terms] OR interleukin[Text Word]) OR (("cytokines"[TIAB] NOT Medline[SB]) OR "cytokines"[MeSH Terms] OR cytokine[Text Word]) AND ("genetic polymorphism"[Text Word] OR "polymorphism, genetic"[MeSH Terms] OR polymorphism[Text Word]) OR SNP[All

Table I: Candidate single nucleotide polymorphisms (SNPs) and their respective probes and primers

\begin{tabular}{|c|c|c|c|c|c|c|}
\hline Gene & Location & SNP ID & Forward primer & Reverse primer & FAM probe & TET probe \\
\hline IL-IA & $+4845 \mathrm{G}>\mathrm{T}$ & rsl756I & $\begin{array}{l}\text { TGCACTTGTGATCAT } \\
\text { GGTTTTAGA }\end{array}$ & $\begin{array}{l}\text { TCCTCATAAAGTTGT } \\
\text { ATTTCACATTGC }\end{array}$ & $\begin{array}{l}\text { CAAGCCTAGGTCATC } \\
\text { ACCTTTTAGCTTCC }\end{array}$ & $\begin{array}{l}\text { AAGCCTAGGTCAGCA } \\
\text { CCTTTTAGCTTCC }\end{array}$ \\
\hline IL-IB & -5||$C>T$ & rsI6944 & $\begin{array}{l}\text { TTGAGGGTGTGGGTC } \\
\text { TCTACCT }\end{array}$ & $\begin{array}{l}\text { AGGAGCCTGAACCCT } \\
\text { GCATAC }\end{array}$ & $\begin{array}{l}\text { TTCTCTGCCTCGGGA } \\
\text { GCTCTCTGT }\end{array}$ & $\begin{array}{l}\text { TTCTCTGCCTCAGGA } \\
\text { GCTCTCTGTCA }\end{array}$ \\
\hline IL-IB & $+3954 \mathrm{C}>\mathrm{T}$ & rsII43634 & $\begin{array}{l}\text { GCCTGCCCTTCTGAT } \\
\text { TTTATACC }\end{array}$ & $\begin{array}{l}\text { CATCGTGCACATAAG } \\
\text { CCTCGTTA }\end{array}$ & $\begin{array}{l}\text { TTCAGAACCTATCTT } \\
\text { CTTTGACACATGGGA }\end{array}$ & $\begin{array}{l}\text { CAGAACCTATCTTCT } \\
\text { TCGACACATGGGA }\end{array}$ \\
\hline IL-IRN & $+2018 \mathrm{~T}>\mathrm{C}$ & rs419598 & $\begin{array}{l}\text { GGGATGTTAACCAGA } \\
\text { AGACCTTCTATCT }\end{array}$ & $\begin{array}{l}\text { CAACCACTCACCTTC } \\
\text { TAAATTGACATT }\end{array}$ & $\begin{array}{l}\text { AACAACCAACTAGTT } \\
\text { GCTGGATACTTGCAA }\end{array}$ & $\begin{array}{l}\text { ACAACCAACTAGTTG } \\
\text { CCGGATACTTGC }\end{array}$ \\
\hline IL-4R & $+1902 A>G$ & rsl80I275 & $\begin{array}{l}\text { AGGCTTGAGAAGGC } \\
\text { CTTGTAA }\end{array}$ & $\begin{array}{l}\text { CCGAAATGTCCTCCA } \\
\text { GCAT }\end{array}$ & $\begin{array}{l}\text { CATGTACAAACTCCT } \\
\text { GATAGCCACTGGTG }\end{array}$ & $\begin{array}{l}\text { CATGTACAAACTCCC } \\
\text { GATAGCCACTGG }\end{array}$ \\
\hline IL-6 & $-174 G>C$ & rs 1800795 & $\begin{array}{l}\text { GCTGATTGGAAACCT } \\
\text { TATTAAGATTGT }\end{array}$ & $\begin{array}{l}\text { AATGACGACCTAAGC } \\
\text { TGCACTTT }\end{array}$ & $\begin{array}{l}\text { ACGTCCTTTAGCATC } \\
\text { GCAAGACACAAC }\end{array}$ & $\begin{array}{l}\text { ACGTCCTTTAGCATG } \\
\text { GCAAGACACAAC }\end{array}$ \\
\hline IL-10 & $-1082 G>A$ & rs 1800896 & $\begin{array}{l}\text { GATAGGAGGTCCCTT } \\
\text { АСTTTCCTCTTA }\end{array}$ & $\begin{array}{l}\text { CACACACAAATCCAA } \\
\text { GACAACACTAC }\end{array}$ & $\begin{array}{l}\text { CTACTTCССССTCCC } \\
\text { AAAGAAGCCT }\end{array}$ & $\begin{array}{l}\text { ССТACTTCСССТTCC } \\
\text { CAAAGAAGCC }\end{array}$ \\
\hline
\end{tabular}

Note: All sequences are from $5^{\prime}$ end to $3^{\prime}$ end.

Table 2: Final concentration of the different constituents of the PCR mixture

\begin{tabular}{|c|c|c|c|c|c|c|c|}
\hline \multirow[t]{2}{*}{ PCR constituents } & \multicolumn{7}{|c|}{ Final concentrations for the various SNPs } \\
\hline & IL I A +4845 & ILIB -5 I I & ILIB +3954 & ILIRN + 2018 & IL4R + I902 & IL6 - I 74 & ILI 0 - I 082 \\
\hline Taqman mastermix (2X) & $\mathrm{IX}$ & IX & IX & IX & $\mathrm{IX}$ & $\mathrm{IX}$ & IX \\
\hline Forward primer $(10 \mu \mathrm{M})$ & $500 \mathrm{nM}$ & $100 \mathrm{nM}$ & $300 \mathrm{nM}$ & $250 \mathrm{nM}$ & $50 \mathrm{nM}$ & $50 \mathrm{nM}$ & $50 \mathrm{nM}$ \\
\hline Reverse primer $(10 \mu \mathrm{M})$ & $500 \mathrm{nM}$ & $100 \mathrm{nM}$ & $300 \mathrm{nM}$ & $250 \mathrm{nM}$ & $500 \mathrm{nM}$ & $50 \mathrm{nM}$ & $300 \mathrm{nM}$ \\
\hline FAM probe $(5 \mu \mathrm{M})$ & $50 \mathrm{nM}$ & $50 \mathrm{nM}$ & $50 \mathrm{nM}$ & $30 \mathrm{nM}$ & $30 \mathrm{nM}$ & $30 \mathrm{nM}$ & $50 \mathrm{nM}$ \\
\hline TET probe $(5 \mu \mathrm{M})$ & $100 \mathrm{nM}$ & $100 \mathrm{nM}$ & $75 \mathrm{nM}$ & $150 \mathrm{nM}$ & $120 \mathrm{nM}$ & $60 \mathrm{nM}$ & $150 \mathrm{nM}$ \\
\hline Template $(20 \mathrm{ng} / \mu \mathrm{l})$ & $0.8 \mathrm{ng} / \mu \mathrm{l}$ & $0.8 \mathrm{ng} / \mu \mathrm{l}$ & $0.8 \mathrm{ng} / \mu \mathrm{l}$ & $0.8 \mathrm{ng} / \mu \mathrm{l}$ & $0.8 \mathrm{ng} / \mu \mathrm{l}$ & $0.8 \mathrm{ng} / \mu \mathrm{l}$ & $0.8 \mathrm{ng} / \mu \mathrm{l}$ \\
\hline
\end{tabular}

Taqman mastermix: Universal PCR mastermix (PE Biosystems) containing $\mathrm{MgCl}_{2}$, dNTPs, Taq polymerase, optimised buffer components and Rox reference dye; FAM probe: 6-carboxy-fluorescein-labelled probe; TET: 6-carboxy-4,7,2',7'-tetrechlorofluorescein-labelled probe. 
Table 3: Cycling conditions for the PCRs for the different polymorphisms

\begin{tabular}{|c|c|c|c|c|c|c|c|c|}
\hline \multirow[t]{2}{*}{ Steps } & \multirow[t]{2}{*}{ Time } & \multicolumn{7}{|c|}{ Temperature for the various SNPs } \\
\hline & & ILIA +4845 & ILIB -5 I I & ILI B +3954 & ILIRN + 20I 8 & IL4R + I902 & IL6 - I 74 & ILI 0 - I 082 \\
\hline I & 2 minutes & $50^{\circ} \mathrm{C}$ & $50^{\circ} \mathrm{C}$ & $50^{\circ} \mathrm{C}$ & $50^{\circ} \mathrm{C}$ & $50^{\circ} \mathrm{C}$ & $50^{\circ} \mathrm{C}$ & $50^{\circ} \mathrm{C}$ \\
\hline 2 & 10 minutes & $95^{\circ} \mathrm{C}$ & $95^{\circ} \mathrm{C}$ & $95^{\circ} \mathrm{C}$ & $95^{\circ} \mathrm{C}$ & $95^{\circ} \mathrm{C}$ & $95^{\circ} \mathrm{C}$ & $95^{\circ} \mathrm{C}$ \\
\hline 3 & 15 seconds & $95^{\circ} \mathrm{C}$ & $95^{\circ} \mathrm{C}$ & $95^{\circ} \mathrm{C}$ & $95^{\circ} \mathrm{C}$ & $95^{\circ} \mathrm{C}$ & $95^{\circ} \mathrm{C}$ & $95^{\circ} \mathrm{C}$ \\
\hline 4 & I minutes & $59^{\circ} \mathrm{C}$ & $59^{\circ} \mathrm{C}$ & $61^{\circ} \mathrm{C}$ & $64^{\circ} \mathrm{C}$ & $61^{\circ} \mathrm{C}$ & $62^{\circ} \mathrm{C}$ & $62^{\circ} \mathrm{C}$ \\
\hline 5 & 40 times & Go to step 3 & Go to step 3 & Go to step 3 & Go to step 3 & Go to step 3 & Go to step 3 & Go to step 3 \\
\hline 6 & Hold & $15^{\circ} \mathrm{C}$ & $15^{\circ} \mathrm{C}$ & $15^{\circ} \mathrm{C}$ & $15^{\circ} \mathrm{C}$ & $15^{\circ} \mathrm{C}$ & $15^{\circ} \mathrm{C}$ & $15^{\circ} \mathrm{C}$ \\
\hline
\end{tabular}

Fields] AND (("neoplasms"[TIAB] NOT Medline[SB]) OR "neoplasms"[MeSH Terms] OR cancer[Text Word]) AND English[Lang]. Only articles on the polymorphisms evaluated in this study were included for the purposes of the review and their results are summarised in the discussion.

\section{Data processing and analysis}

All data were entered initially into a Microsoft Access database and exported to SPSS (version 12.0.1 for Windows) for statistical analyses. Chi-square test for trend was performed to compare the genotype frequencies $(1: 1,1: 2$ and 2:2 representing the common homozygous, heterozygous and the rare heterozygous respectively) between cases and controls and also for comparison of the genotype frequencies among the various subgroups of breast cancer. Kaplan Meier curves and the log rank test was used for the survival analyses. All tests were two sided. Haplotype analysis was then performed on the genotype data of the four polymorphisms (IL1A +4845G >T, IL1B +3954C >T, IL1B -511C>T and IL1RN +2018T>C) in chromosomal region $2 \mathrm{q} 13$ using Haploview [56].

\section{Results}

The demographic characteristics and comparability of case and control cohorts have been reported previously $[53,54]$. Briefly, the case and control groups were all Caucasian and female. There were no significant differences in the percentage of postmenopausal women, age at menarche and age at menopause between the cancer and control groups. The women in the control groups were however younger [median (IQR) of 57 (53-61) in the control group vs. 63 (54-70) in the cancer group; p < 0.001; Mann-Whitney U test], were younger when first pregnant [median (IQR) of $23(20-26)$ in the control group vs. $24(21-27)$ in the cancer group; $\mathrm{p}<0.001$; Mann-Whitney U test], had more children [median (IQR) of $2(2-3)$ in the control group vs. $2(1-3)$ in the cancer group; $\mathrm{p}<0.001$; Mann-Whitney U test], were less likely to have a family history of breast cancer $[22.2 \%$ in controls vs. $27.4 \%$ in cancers; $\mathrm{p}=0.007$; Chi-square test] and were more likely not to have smoked $[63.1 \%$ in controls vs. $53.4 \%$ in cancers; $\mathrm{p}<0.001$; Chi-square test].
Table 4 shows the total numbers, the observed frequencies and the expected genotype frequencies (expected genotype frequencies were calculated from the respective allele frequencies) in the control population and the testing for the Hardy Weinberg Equilibrium. The observed frequencies of the genotypes for all polymorphisms are not significantly different from the expected frequencies except for the IL1A +4845 and the IL4R +1902 polymorphisms.

The comparison of genotype frequencies between the control and cancer groups for each of the polymorphisms (along with the actual numbers studied) are shown in Table 5. In addition to overall comparisons, the genotype frequencies were compared in subgroups classified according to family history and age at diagnosis. Table 6 shows the genotype frequencies for the seven polymorphisms within subgroups of invasive breast cancer (defined by tumour grade, nodal status and vascular invasion). Figures 1, 2, 3, 4, 5, 6, 7, 8 show survival curves demonstrating that none of the polymorphisms had any impact on time to death or development of metastases in those with invasive breast cancer.

Further analyses of the four polymorphisms in the Interleukin-1 gene cluster (IL1A +4845G $>$ T, IL1B +3954C $>$ T, IL1B $-511 \mathrm{C}>\mathrm{T}$ and IL1RN +2018T>C) were done using Haploview. These four polymorphisms are situated a region of size $360 \mathrm{~kb}$. The $\mathrm{LD}$ (linkage disequilibrium) values for the four pairs of SNPs (Figure 8) and the probable haplotypes with their frequencies (Table 7) have been calculated. None of the estimated haplotypes was associated with breast cancer in this cohort.

The literature search demonstrated two previous studies on the IL1B $-511 \mathrm{C}>\mathrm{T}$ polymorphism $[57,58]$, one on the IL1B +3954C>T polymorphism [58], six on the IL6 $174 \mathrm{G}>\mathrm{C}$ polymorphism Smith, $2004 \# 877\}$ [58-62] and four on the IL10 $-1082 \mathrm{G}>$ A polymorphism $[57,59,63,64]$. The results of the previously published studies are discussed in the context of the results from the current study in the next section. 
Table 4: Observed and Expected genotype frequencies and the HardyWeinberg Equilibrium in the control population

\begin{tabular}{|c|c|c|c|c|c|c|c|c|c|c|}
\hline \multirow[t]{2}{*}{ SNP } & \multirow[t]{2}{*}{$\begin{array}{l}\text { Controls } \\
\text { (n) }\end{array}$} & \multicolumn{3}{|c|}{ Observed Genotype Frequency } & \multicolumn{2}{|c|}{$\begin{array}{l}\text { Allele Frequency } \\
\text { (in \%) }\end{array}$} & \multicolumn{2}{|c|}{$\begin{array}{l}\text { Expected Genotype } \\
\text { Frequency }\end{array}$} & \multicolumn{2}{|c|}{$\begin{array}{l}\text { Chi-square Goodness } \\
\text { of fit test statistic (p } \\
\text { value) }\end{array}$} \\
\hline & & I:I & $1: 2$ & $2: 2$ & $\mathbf{I}$ & 2 & I:I & $1: 2$ & $2: 2$ & $2: 2$ \\
\hline ILIA +4845 & 498 & 215 & 245 & 38 & 67.8 & 32.2 & 229 & 217 & 52 & $\begin{array}{l}\chi^{2}=7.49 \\
p=0.01\end{array}$ \\
\hline ILIB -5 I I & 489 & 232 & 206 & 51 & 66.5 & 31.5 & 230 & 211 & 48 & $\begin{array}{l}\chi^{2}=0.20 \\
p=0.66\end{array}$ \\
\hline ILIB +3954 & 420 & 231 & 167 & 22 & 74.9 & 25.1 & 235 & 158 & 27 & $\begin{array}{l}\chi^{2}=1.13 \\
p=0.29\end{array}$ \\
\hline ILIRN +20I 8 & 490 & 247 & 202 & 41 & 71 & 29 & 247 & 202 & 41 & $\begin{array}{l}\chi^{2}=0 \\
p=0.95\end{array}$ \\
\hline IL4R + 1902 & 767 & 451 & 288 & 28 & 77.6 & 22.4 & 461 & 267 & 39 & $\begin{array}{l}\chi^{2}=4.45 \\
p=0.03\end{array}$ \\
\hline IL6 - I 74 & 490 & 168 & 235 & 87 & 58.3 & 41.7 & 167 & 238 & 85 & $\begin{array}{l}\chi^{2}=0.06 \\
p=0.81\end{array}$ \\
\hline ILI 0 - I 082 & 498 & 117 & 260 & 121 & 49.6 & 50.4 & 123 & 249 & 126 & $\begin{array}{l}\chi^{2}=0.85 \\
p=0.36\end{array}$ \\
\hline
\end{tabular}

\section{Discussion}

Cytokines play varied roles in cancer pathogenesis with increasing evidence suggesting their involvement in tumour initiation, growth and metastasis [1]. Cytokine gene polymorphisms have been studied for associations with many inflammatory and neoplastic diseases. Numerous reports have evaluated the association of individual candidate SNPs in cytokine genes in breast cancer, some of which are included in this study.

\section{ILIA polymorphisms and breast cancer}

IL1A is thought to contribute to breast cancer expression by up-regulating pro-metastatic genes in breast cancer cells and stromal cells [65]. IL1A levels in breast tissue homogenates correlates inversely with ER levels [66], which is an established prognostic marker in breast cancer. The IL1A gene is mapped to chromosome 2q13 and includes several polymorphisms, of which one in the 5 'UTR regulatory region $(-889 \mathrm{C}>\mathrm{T})$ and one in exon 5 of the gene $(+4845 \mathrm{G}>\mathrm{T})$ have been commonly studied. The IL1A -889 polymorphism has been studied in two different cohorts and not shown to be associated with breast cancer $[58,67]$. However, to date, there are no published studies on the role of the IL1A +4845 polymorphism in breast cancer. The current study has shown that there is a trend for the rare allele to confer a protective effect against cancer ( $p=0.05)$ and for the common allele to be significantly associated with lymph node positive cancers ( $\mathrm{p}=$ 0.03). This effect is more apparent when the rare allele carriage rates (carriers of rare alleles) are assessed instead of genotype frequencies $(\mathrm{p}=0.005$ and $\mathrm{p}=0.007$ respectively). The positive finding however has not been subject to corrections for multiple testing in view of the exploratory nature of these studies. In addition, given that the genotype frequencies of this polymorphism were not in
Hardy Weinberg equilibrium, this may be an artefactual association which would need confirmation in other populations. There was no association of this polymorphism with tumour grade, vessel invasion or survival.

\section{IL I B polymorphisms and breast cancer}

IL1 $\beta$ levels are high in breast cancer tissue and correlate with invasiveness and an aggressive phenotype [68]. They seem to regulate cancer cell proliferation through oestrogen production by steroid-catalyzing enzymes in the tissue [69]. The IL1B gene is mapped to $2 q 13$ [70] and the commonly described genetic variants include the $511 \mathrm{C}>\mathrm{T}$ and the $-31 \mathrm{C}>\mathrm{T}$ in the 5 'UTR and the $+3954 \mathrm{C}>\mathrm{T}$ polymorphism in exon 5 of the gene. Our data for the 511 and the +3954 SNPs show that overall; neither of these SNPs is associated with breast cancer susceptibility, severity or survival. As table $4 \mathrm{c}$ shows, in women with a positive family history of breast cancer, the IL1B $+3954 \mathrm{~T}$ allele was associated with a reduced risk of breast cancer. The significance of this association on exploratory subgroup analysis is however limited. Tables 8 and 9 show data from two other studies confirming our findings that these polymorphisms do play a significant role in breast cancer susceptibility or severity.

\section{ILIRN polymorphisms and breast cancer}

It has been shown that IL1RA levels are increased in breast cancer tissue and that IL1RA levels correlate with ER levels [66]. At least 18 sequence variants exist around the IL1RN gene [71] located in chromosome $2 q 13$ [70]. Of these, the penta-allelic variant in intron 2 and the $+2018 \mathrm{~T}>\mathrm{C}$ have been commonly studied. There are no prior reports of the IL1RN +2018 polymorphism in breast cancer. The intronic polymorphism described however has however been studied in breast cancer without any significant asso- 
Table 5: Genotype frequencies of the seven polymorphisms in subgroups of breast cancer and control populations

\begin{tabular}{|c|c|c|c|c|c|}
\hline \multirow[t]{2}{*}{ Subsets } & \multirow[t]{2}{*}{ Case/control } & \multicolumn{3}{|c|}{ Genotype Frequencies (\%) } & \multirow[t]{2}{*}{ Chi square test for trend ( $p$ value) } \\
\hline & & I:I & $\mathrm{I}: 2$ & $2: 2$ & \\
\hline \multicolumn{6}{|l|}{ ILIA +4845 G>T } \\
\hline \multirow[t]{2}{*}{ Overall } & Cancers $(n=697)$ & $360(51.6 \%)$ & 275 (39.5\%) & $62(8.9 \%)$ & $X^{2}=3.7 I ; p=0.05$ \\
\hline & Controls $(n=498)$ & $215(43.2 \%)$ & 245 (49.2\%) & $38(7.6 \%)$ & \\
\hline \multirow[t]{2}{*}{ Positive Family History } & Cancers $(n=192)$ & 106 (55.2\%) & 7I (37\%) & 15 (7.8\%) & $X^{2}=2.74 ; p=0.10$ \\
\hline & Controls $(n=104)$ & $44(42.3 \%)$ & $52(50 \%)$ & $8(7.7 \%)$ & \\
\hline \multirow[t]{2}{*}{ Negative Family History } & Cancers $(n=505)$ & $254(50.3 \%)$ & $204(40.4 \%)$ & $47(9.3 \%)$ & $X^{2}=1.47 ; p=0.23$ \\
\hline & Controls $(n=394)$ & $171(43.4 \%)$ & $193(49 \%)$ & $30(7.6 \%)$ & \\
\hline \multirow[t]{2}{*}{ Young cancers vs. controls } & Cancers $(n=113)$ & $55(48.7 \%)$ & $43(38 \%)$ & $15(13.3 \%)$ & $X^{2}=0 ; p=0.98$ \\
\hline & Controls $(n=498)$ & $215(43.2 \%)$ & 245 (49.2\%) & 38 (7.6\%) & \\
\hline
\end{tabular}

\section{ILIB -5 I I C>T}

\begin{tabular}{llllll}
\hline Overall & Cancers $(n=703)$ & $339(48.2 \%)$ & $294(41.8 \%)$ & $70(10 \%)$ & $X^{2}=0.10 ; p=0.75$ \\
& Controls $(n=489)$ & $232(47.4 \%)$ & $206(42.1 \%)$ & $51(10.4 \%)$ & \\
Positive Family History & Cancers $(n=195)$ & $96(49.2 \%)$ & $85(43.6 \%)$ & $14(7.2 \%)$ & $X^{2}=0.45 ; p=0.51$ \\
& Controls $(n=103)$ & $48(46.6 \%)$ & $45(43.7 \%)$ & $10(9.7 \%)$ & \\
Negative Family History & Cancers $(n=508)$ & $243(47.8 \%)$ & $209(41.1 \%)$ & $56(11 \%)$ & $X^{2}=0.003 ; p=0.96$ \\
& Controls $(n=386)$ & $184(47.7 \%)$ & $161(41.7 \%)$ & $41(10.6 \%)$ & \\
Young cancers vs. controls & Cancers $(n=115)$ & $55(47.8 \%)$ & $49(42.6 \%)$ & $11(9.6 \%)$ & $X^{2}=0.033 ; p=0.86$ \\
& Controls $(n=489)$ & $232(47.4 \%)$ & $206(42.1 \%)$ & $51(10.4 \%)$ &
\end{tabular}

\section{ILIB +3954 C>T}

\begin{tabular}{llllll}
\hline Overall & Cancers $(n=691)$ & $410(59.3 \%)$ & $242(35 \%)$ & $39(5.6 \%)$ & $X^{2}=1.12 ; p=0.29$ \\
& Controls $(n=420)$ & $231(55 \%)$ & $167(39.8 \%)$ & $22(5.2 \%)$ & \\
Positive Family History & Cancers $(n=193)$ & $129(66.8 \%)$ & $55(28.5 \%)$ & $9(4.7 \%)$ & $X^{2}=8.75 ; p=0.003 *$ \\
& Controls $(n=91)$ & $43(47.3 \%)$ & $41(45.1 \%)$ & $7(7.7 \%)$ & \\
Negative Family History & Cancers $(n=498)$ & $281(56.4 \%)$ & $187(37.6 \%)$ & $30(6 \%)$ & $X^{2}=0.26 ; p=0.61$ \\
& Controls $(n=329)$ & $188(57.1 \%)$ & $126(38.3 \%)$ & $15(4.6 \%)$ & \\
Young cancers vs. controls & Cancers $(n=112)$ & $64(57.1 \%)$ & $41(36.6 \%)$ & $7(6.3 \%)$ & $X^{2}=0.03 ; p=0.86$ \\
& Controls $(n=420)$ & $231(55 \%)$ & $167(39.8 \%)$ & $22(5.2 \%)$ &
\end{tabular}

\section{ILIRN +20I8 T>C}

\begin{tabular}{llllll}
\hline Overall & Cancers $(n=697)$ & $349(50.1 \%)$ & $286(41 \%)$ & $62(8.9 \%)$ & $X^{2}=0.05 ; p=0.82$ \\
& Controls $(n=490)$ & $247(50.4 \%)$ & $202(41.2 \%)$ & $41(8.4 \%)$ & \\
Positive Family History & Cancers $(n=193)$ & $94(48.7 \%)$ & $84(43.5 \%)$ & $15(7.8 \%)$ & $X^{2}=0.074 ; p=0.79$ \\
& Controls $(n=103)$ & $48(46.6 \%)$ & $47(45.6 \%)$ & $8(7.8 \%)$ & \\
Negative Family History & Cancers $(n=504)$ & $255(50.6 \%)$ & $202(40.1 \%)$ & $47(9.3 \%)$ & $X^{2}=0.14 ; p=0.71$ \\
& Controls $(n=387)$ & $199(51.4 \%)$ & $155(40.1 \%)$ & $33(8.5 \%)$ & \\
Young cancers vs. controls & Cancers $(n=113)$ & $61(54 \%)$ & $44(38.9 \%)$ & $8(7.1 \%)$ & $X^{2}=0.53 ; p=0.47$ \\
& Controls $(n=490)$ & $247(50.4 \%)$ & $202(41.2 \%)$ & $41(8.4 \%)$ &
\end{tabular}

\section{IL4R + I902 A>G}

\begin{tabular}{llllll}
\hline Overall & Cancers $(n=775)$ & $493(63.6 \%)$ & $249(32.1 \%)$ & $33(4.3 \%)$ & $X^{2}=2.1 ; p=0.15$ \\
& Controls $(n=767)$ & $451(58.8 \%)$ & $288(37.5 \%)$ & $28(3.7 \%)$ & \\
Positive Family History & Cancers $(n=212)$ & $133(62.7 \%)$ & $70(33 \%)$ & $9(4.2 \%)$ & $X^{2}=0.19 ; p=0.66$ \\
& Controls $(n=168)$ & $98(58.3 \%)$ & $66(39.3 \%)$ & $4(2.4 \%)$ & \\
Negative Family History & Cancers $(n=563)$ & $360(63.9 \%)$ & $179(31.8 \%)$ & $24(4.3 \%)$ & $X^{2}=2.00 ; p=0.16$ \\
& Controls $(n=599)$ & $353(58.9 \%)$ & $222(37.1 \%)$ & $24(4.0 \%)$ & \\
Young cancers vs. controls & Cancers $(n=122)$ & $85(69.7 \%)$ & $36(29.5 \%)$ & $1(0.8 \%)$ & $X^{2}=6.36 ; p=0.012^{*}$ \\
& Controls $(n=767)$ & $451(58.8 \%)$ & $288(37.5 \%)$ & $28(3.7 \%)$ & \\
& & & &
\end{tabular}

\section{IL6 - I74 G>C}


Table 5: Genotype frequencies of the seven polymorphisms in subgroups of breast cancer and control populations (Continued)

\begin{tabular}{|c|c|c|c|c|c|}
\hline \multirow[t]{2}{*}{ Overall } & Cancers $(n=497)$ & $170(34.2 \%)$ & $244(49.1 \%)$ & $83(16.7 \%)$ & $X^{2}=0.05 ; p=0.83$ \\
\hline & Controls $(n=490)$ & $168(34.3 \%)$ & $235(48 \%)$ & 87 (I7.8\%) & \\
\hline \multirow[t]{2}{*}{ Positive Family History } & Cancers $(n=127)$ & $47(37 \%)$ & 55 (43.3\%) & $25(19.7 \%)$ & $X^{2}=0.20 ; p=0.66$ \\
\hline & Controls $(n=102)$ & $38(37.3 \%)$ & $48(47.1 \%)$ & $16(15.7 \%)$ & \\
\hline \multirow[t]{2}{*}{ Negative Family History } & Cancers $(n=370)$ & $123(33.2 \%)$ & $189(51.1 \%)$ & $58(15.7 \%)$ & $X^{2}=1.22 ; p=0.64$ \\
\hline & Controls $(n=388)$ & $130(33.5 \%)$ & $187(48.2 \%)$ & 71 (18.3\%) & \\
\hline \multirow[t]{2}{*}{ Young cancers vs. controls } & Cancers $(n=85)$ & $36(42.4 \%)$ & $31(36.5 \%)$ & $18(21.2 \%)$ & $X^{2}=0.31 ; p=0.58$ \\
\hline & Controls $(n=490)$ & $168(34.3 \%)$ & $235(48 \%)$ & 87 (17.8\%) & \\
\hline \multicolumn{6}{|l|}{ ILI 0 - I 082 G>A } \\
\hline \multirow[t]{2}{*}{ Overall } & Cancers $(n=497)$ & $121(24.3 \%)$ & $253(50.9 \%)$ & $123(24.7 \%)$ & $X^{2}=0.01 ; p=0.93$ \\
\hline & Controls $(n=498)$ & 117 (23.5\%) & $260(52.2 \%)$ & $121(24.3 \%)$ & \\
\hline \multirow[t]{2}{*}{ Positive Family History } & Cancers $(n=126)$ & $31(24.6 \%)$ & $69(54.8 \%)$ & $26(20.6 \%)$ & $X^{2}=0.39 ; p=0.54$ \\
\hline & Controls $(n=104)$ & $31(29.8 \%)$ & $52(50 \%)$ & $21(20.2 \%)$ & \\
\hline \multirow[t]{2}{*}{ Negative Family History } & Cancers $(n=37 I)$ & $90(24.3 \%)$ & $184(49.6 \%)$ & $97(26.1 \%)$ & $X^{2}=0.11 ; p=0.74$ \\
\hline & Controls $(n=394)$ & $86(21.8 \%)$ & $208(52.8 \%)$ & $100(25.4 \%)$ & \\
\hline \multirow[t]{2}{*}{ Young cancers vs. controls } & Cancers $(n=84)$ & 17 (20.2\%) & $44(52.4 \%)$ & $23(27.4 \%)$ & $X^{2}=0.60 ; p=0.44$ \\
\hline & Controls $(n=498)$ & $117(23.5 \%)$ & $260(52.2 \%)$ & $12 \mid(24.3 \%)$ & \\
\hline
\end{tabular}

Note: Family history: either first or second degree relative with breast cancer. Young cancer patients: $</=50$ years of age

ciation with susceptibility or prognosis [58]. Our data shows no association of the $+2018 \mathrm{~T}>\mathrm{C}$ polymorphism with breast cancer risk, severity or survival from the disease.

In addition to the analysis of the individual polymorphisms in the IL1A, IL1B and IL1RN genes, comparison of the probable haplotype frequencies in the breast cancer and control cohorts did not show any significant differences between the two groups.

\section{IL4R polymorphisms and breast cancer}

IL4 receptor is significantly expressed in breast cancer [72] and it has been shown that IL4R is required for actions of IL4 on breast cancer cells [12] including the inhibition of growth and induction of apoptosis. The IL4R gene has been localised to $16 \mathrm{p} 12$. Several coding and regulatory region polymorphisms exist in the IL4R gene and are thought to influence signal transduction on the IL4 signalling pathway [73]. Our data on the IL4R polymorphism $+1902 \mathrm{~A}>\mathrm{G}$ has shown no overall association with breast cancer susceptibility, severity or survival. In the subgroup of young cancer patients (those $</=50$ years at diagnosis), we found that the $G$ allele was significantly associated with breast cancer. There are no other studies of this polymorphism in breast cancer.

\section{IL6 polymorphisms and breast cancer}

The circulating level of interleukin 6 is thought to be elevated in the development and progression of many tumours including breast cancer and its up-regulation is associated with invasiveness and increased metastatic potential of ER negative tumours [74]. The IL6 gene has been localised to chromosome $7 \mathrm{p} 21$. Although several polymorphisms exist in the promoter region of IL- 6 and are thought to have a complex interactive effect on IL6 expression [75], the polymorphism at -174 has been most extensively studied and shown to have significant ethnic variation [74]. Table 10 shows the various studies of this polymorphism in breast cancer to date. Only one study demonstrated an association with breast cancer susceptibility [58], which showed a significant Odds ratio of 1.5 and 2.0 for the heterozygotes (GC) and the rare homozygotes (CC) when compared to the common homozygotes (GG). The study however included a non-healthy control population (women attending outpatient departments for various reasons) and a lack of correction for multiple testing. Our data shows that the IL6 -174G $>$ C polymorphism was not associated with either breast cancer risk or severity and prognosis as assessed by tumour grade, lymph nodal status, vascular invasion or survival.

\section{ILI 0 polymorphisms and breast cancer}

IL10 has been shown to have anti-metastatic and antitumour effects in murine breast cancer models [17]. Mononuclear cells from breast cancer patients exhibit increased IL10 production [76] and IL10 serum levels correlate with stage of the disease [77]. Several single nucleotide polymorphisms exist in the promoter region of the IL10 gene (localised to chromosome 1q31-q32) including $-1082,-819$ and -592 [78]. Table 11 shows the studies of the IL10 $-1082 \mathrm{G}>\mathrm{A}$ polymorphism in breast cancer. Of the three studies reported, only one suggests a role for the $\mathrm{G}$ allele in reducing breast cancer risk [63]. Our data, which includes larger numbers of individuals, however shows no association with breast cancer susceptibility, 
Table 6: Genotype frequencies of the seven polymorphisms in subgroups of invasive breast cancer.

\begin{tabular}{|c|c|c|c|c|c|}
\hline \multirow[t]{2}{*}{ Tumour Severity } & \multirow[t]{2}{*}{ Subgroups } & \multicolumn{3}{|c|}{ Genotype frequencies (\%) } & \multirow[t]{2}{*}{ Chi square test for trend ( $P$ value) } \\
\hline & & I:I & $1: 2$ & $2: 2$ & \\
\hline \multicolumn{6}{|l|}{ ILIA +4845 G>T } \\
\hline \multirow[t]{3}{*}{ Tumour Grade } & Grade I $(n=122)$ & $62(50.8 \%)$ & $50(4 \mid \%)$ & $10(8.2 \%)$ & $X^{2}=0.037 ; p=0.85$ \\
\hline & Grade $2(n=283)$ & I5I (53.4\%) & $109(38.5 \%)$ & $23(8.1 \%)$ & \\
\hline & Grade $3(n=216)$ & II 5 (53.2\%) & $82(38 \%)$ & $19(8.8 \%)$ & \\
\hline \multirow[t]{2}{*}{ Nodal Involvement } & Absent $(n=430)$ & $204(47.4 \%)$ & $118(43.7 \%)$ & 38 (8.8\%) & $X^{2}=4.75 ; p=0.03 *$ \\
\hline & Present $(n=117)$ & 117 (59.4\%) & $63(32 \%)$ & $17(8.6 \%)$ & \\
\hline \multirow[t]{2}{*}{ Vascular Invasion } & Absent $(n=467)$ & $243(52 \%)$ & $185(39.6 \%)$ & $39(8.4 \%)$ & $X^{2}=0.058 ; p=0.81$ \\
\hline & Present $(n=117)$ & $64(54.7 \%)$ & $42(35.9 \%)$ & II (9.4\%) & \\
\hline
\end{tabular}

\section{ILIB -5 I I C>T}

\begin{tabular}{|c|c|c|c|c|c|}
\hline \multirow{3}{*}{ Tumour Grade } & Grade I $(n=126)$ & $5 \mathrm{I}(40.5 \%)$ & $59(46.8 \%)$ & $16(12.7 \%)$ & $X^{2}=0.12 ; p=0.73$ \\
\hline & Grade $2(n=284)$ & $150(52.8 \%)$ & $111(39.1 \%)$ & $23(8.1 \%)$ & \\
\hline & Grade $3(n=216)$ & $98(45.4 \%)$ & $93(43.1 \%)$ & 25 (II.6\%) & \\
\hline \multirow[t]{2}{*}{ Nodal Involvement } & Absent $(n=434)$ & $214(49.3 \%)$ & $179(4 \mid .2 \%)$ & $4 \mathrm{I}(9.4 \%)$ & $X^{2}=0.79 ; p=0.37$ \\
\hline & Present $(n=198)$ & $90(45.5 \%)$ & $87(43.9 \%)$ & $21(10.6 \%)$ & \\
\hline \multirow{2}{*}{ Vascular Invasion } & Absent $(n=473)$ & $224(47.4 \%)$ & $201(42.5 \%)$ & 48 (10.1\%) & $X^{2}=0.38 ; p=0.54$ \\
\hline & Present $(n=116)$ & $57(49.1 \%)$ & $50(43.1 \%)$ & $9(7.8 \%)$ & \\
\hline
\end{tabular}

\section{ILIB +3954 C>T}

\begin{tabular}{|c|c|c|c|c|c|}
\hline \multirow[t]{3}{*}{ Tumour Grade } & Grade I $(n=12 I)$ & $68(56.2 \%)$ & 48 (39.7\%) & $5(4.1 \%)$ & $X^{2}=0.053 ; p=0.82$ \\
\hline & Grade $2(n=279)$ & $173(62 \%)$ & $90(32.3 \%)$ & $16(5.7 \%)$ & \\
\hline & Grade $3(n=215)$ & $131(60.9 \%)$ & $70(32.6 \%)$ & $14(6.5 \%)$ & \\
\hline \multirow[t]{2}{*}{ Nodal Involvement } & Absent $(n=427)$ & $244(57.1 \%)$ & $161(37.7 \%)$ & $22(5.2 \%)$ & $X^{2}=0.37 ; p=0.54$ \\
\hline & Present $(n=194)$ & $120(61.9 \%)$ & $61(31.4 \%)$ & $13(6.7 \%)$ & \\
\hline \multirow[t]{2}{*}{ Vascular Invasion } & Absent $(n=464)$ & $283(61 \%)$ & $157(33.8 \%)$ & $24(5.2 \%)$ & $X^{2}=0.43 ; p=0.51$ \\
\hline & Present $(n=1 \mid 4)$ & $66(57.9 \%)$ & $4 \mid(36 \%)$ & $7(6.1 \%)$ & \\
\hline
\end{tabular}

\section{ILIRN +20I8 T>C}

\begin{tabular}{|c|c|c|c|c|c|}
\hline \multirow[t]{3}{*}{ Tumour Grade } & Grade I $(n=125)$ & $55(44 \%)$ & $55(44 \%)$ & $15(12 \%)$ & $X^{2}=0.73 ; p=0.40$ \\
\hline & Grade $2(n=280)$ & $150(53.6 \%)$ & $107(38.2 \%)$ & $23(8.2 \%)$ & \\
\hline & Grade $3(n=215)$ & $108(50.2 \%)$ & $86(40 \%)$ & 21 (9.8\%) & \\
\hline \multirow{2}{*}{ Nodal Involvement } & Absent $(n=429)$ & $216(50.3 \%)$ & $180(42 \%)$ & $33(7.7 \%)$ & $X^{2}=0.11 ; p=0.74$ \\
\hline & Present $(n=196)$ & $102(52 \%)$ & $72(36.7 \%)$ & 22 (II.2\%) & \\
\hline \multirow[t]{2}{*}{ Vascular Invasion } & Absent $(n=463)$ & $232(50.1 \%)$ & $191(41.3 \%)$ & $40(8.6 \%)$ & $X^{2}=1.34 ; p=0.25$ \\
\hline & Present $(\mathrm{n}=118)$ & $67(56.8 \%)$ & $42(35.6 \%)$ & $9(7.6 \%)$ & \\
\hline
\end{tabular}

\section{IL4R + I902 A>G}

\begin{tabular}{llllll}
\hline Tumour Grade & Grade I $(n=137)$ & $87(63.5 \%)$ & $44(32.1 \%)$ & $6(4.4 \%)$ & $X^{2}=0.14 ; p=0.71$ \\
& Grade $(n=308)$ & $195(63.3 \%)$ & $97(31.5 \%)$ & $16(5.2 \%)$ & \\
& Grade $3(n=228)$ & $146(64 \%)$ & $75(32.9 \%)$ & $7(3.1 \%)$ & \\
Nodal Involvement & Absent $(n=477)$ & $313(65.6 \%)$ & $144(30.2 \%)$ & $20(4.2 \%)$ & $X^{2}=0.11 ; p=0.75$ \\
& Present $(n=212)$ & $135(63.7 \%)$ & $69(32.5 \%)$ & $8(3.8 \%)$ & \\
Vascular Invasion & Absent $(n=508)$ & $316(62.2 \%)$ & $170(33.5 \%)$ & $22(4.3 \%)$ & $X^{2}=0.002 ; p=0.96$ \\
& Present $(n=129)$ & $82(63.6 \%)$ & $40(31 \%)$ & $7(5.4 \%)$ &
\end{tabular}

\section{IL6 - I 74 G>C}

\begin{tabular}{lllll}
\hline Tumour Grade & Grade I $(n=80)$ & $26(32.5 \%)$ & $38(47.5 \%)$ & $16(20 \%)$
\end{tabular}$\quad X^{2}=0.04 ; p=0.84$


Table 6: Genotype frequencies of the seven polymorphisms in subgroups of invasive breast cancer. (Continued)

\begin{tabular}{|c|c|c|c|c|c|}
\hline \multirow[t]{2}{*}{ Nodal Involvement } & Absent $(n=293)$ & $100(34.1 \%)$ & $14 \mid(48.1 \%)$ & $52(17.7 \%)$ & $X^{2}=0.20 ; p=0.66$ \\
\hline & Present $(n=143)$ & $52(36.4 \%)$ & 67 (46.9\%) & $24(16.8 \%)$ & \\
\hline \multirow[t]{2}{*}{ Vascular Invasion } & Absent $(n=325)$ & $112(34.5 \%)$ & 159 (48.9\%) & $54(16.6 \%)$ & $X^{2}=0.001 ; p=0.98$ \\
\hline & Present $(n=85)$ & $29(34.1 \%)$ & $42(49.4 \%)$ & $14(16.5 \%)$ & \\
\hline \multicolumn{6}{|l|}{ ILI 0 - I082 G>A } \\
\hline \multirow[t]{3}{*}{ Tumour Grade } & Grade I $(n=80)$ & $23(28.8 \%)$ & 37 (46.3\%) & $20(25 \%)$ & $X^{2}=0.37 ; p=0.54$ \\
\hline & Grade $2(n=205)$ & 39 (19\%) & $113(55.1 \%)$ & $53(25.9 \%)$ & \\
\hline & Grade $3(n=158)$ & $44(27.8 \%)$ & $79(50 \%)$ & 35 (22.2\%) & \\
\hline \multirow[t]{2}{*}{ Nodal Involvement } & Absent $(n=293)$ & 69 (23.5\%) & I 48 (50.5\%) & 76 (25.9\%) & $X^{2}=0.84 ; p=0.36$ \\
\hline & Present $(n=143)$ & $38(26.6 \%)$ & $73(51 \%)$ & 32 (22.4\%) & \\
\hline \multirow[t]{2}{*}{ Vascular Invasion } & Absent $(n=325)$ & $87(26.8 \%)$ & $156(48 \%)$ & $82(25.2 \%)$ & $X^{2}=3.3 ; p=0.07$ \\
\hline & Present $(n=85)$ & $12(14.1 \%)$ & 49 (57.6\%) & 24 (28.2\%) & \\
\hline
\end{tabular}

severity or survival for this polymorphism. A study on the related polymorphism $(-592 \mathrm{C}>\mathrm{A})$ in the promoter region was associated with a reduced breast cancer risk, although in breast cancer patients, there was no association with severity of the disease [79].

\section{Limitations}

Although our study had more than twice the number of subjects than the similar studies on cytokine polymorphisms in breast cancer, it could still be argued that associations of a minor degree (Odds Ratio < 1.5) of the genetic markers studied or other related markers may have been missed. For example, to detect a rare marker (of frequency $10 \%$ ) associated with a 1.3 times increased risk of breast cancer (Odds Ratio $=1.3$ ) with a power of $80 \%$ and type I error of $0.5 \%$, we would need a sample size of 2400 patients and controls. The second limitation is that a small proportion of our control population would develop breast cancer in their lifetime. However, it is generally considered difficult to obtain an ideal control cohort for genetic epidemiologic studies in solid cancers mainly due to the delayed onset of the disease. The prognostic markers used for assessing breast cancer severity in this study were limited to grade, lymph nodal status and vascular invasion due to limited information available on other indices such as hormone receptor status and tumour size.

\section{Conclusion}

The results from our study do not support the hypothesis that the cytokine polymorphisms studied [IL1A $+4845 \mathrm{G}>\mathrm{T}$, IL1B $-511 \mathrm{C}>\mathrm{T}$, IL1B +3954C >T, IL1RN $+2018 \mathrm{~T}>\mathrm{C}$, IL4R -1902A>G， IL6-174G>C and IL10$1082 \mathrm{G}>\mathrm{A}]$ are associated with breast cancer susceptibility and severity. Minor influences and associations with subgroups of phenotypes may exist, but are unlikely to be of any major clinical significance.
Abbreviations

IL: interleukin; ER: oestrogen receptor; SNP: single nucleotide polymorphism; UTR: untranslated region; PCR: polymerase chain reaction; DNA: deoxyribonucleic acid.

\section{Competing interests}

The author(s) declare that they have no competing interests.

\section{Authors' contributions}

SPB, IAFA and SEH carried out patient recruitment, the molecular genetic studies and drafted the manuscript. SSC reviewed the pathology and drafted the manuscript. SPB and AC participated in the design of the study and performed the statistical analysis. AGW, NJB and MWR conceived of the study, and participated in its design and coordination and helped to draft the manuscript. All authors read and approved the final manuscript.

\section{Acknowledgements}

We would like to thank Helen Cramp, Jane McDaid and Claire Greaves for help with recruitment and genotyping, Dan Connley for data management, and all the people who took part in the study. AC is funded by the Yorkshire Cancer Research. We would also like to thank the Royal College of Surgeons of Edinburgh who provided financial assistance towards consumables for this study. 


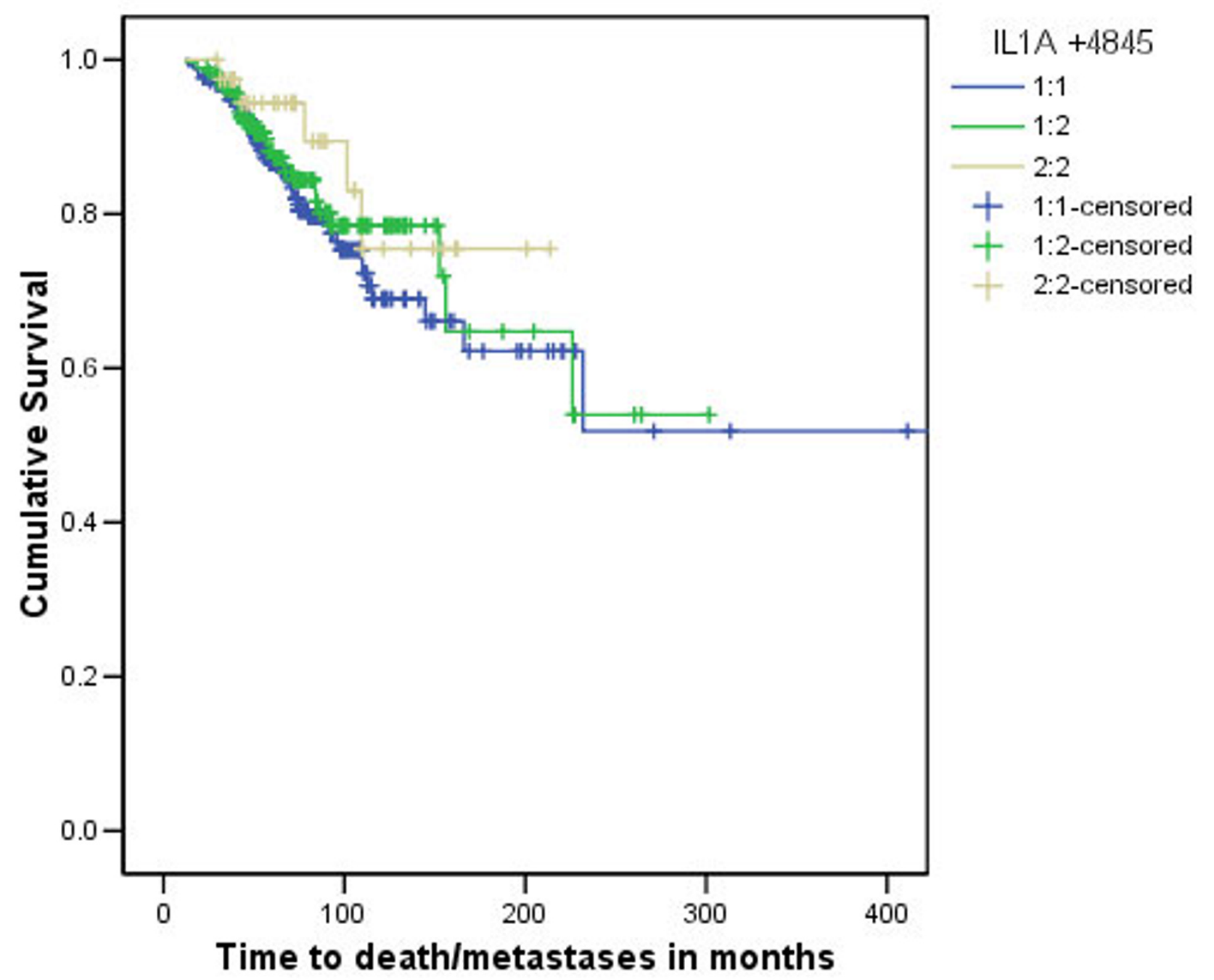

Figure I

shows the time to death or metastases in invasive breast cancer for the genotypes of the ILI A +4845 polymorphism. Log Rank test statistic $=1.52 ; \mathrm{df}=2 ; \mathrm{p}=0.47(\mathrm{n}=482)$. 


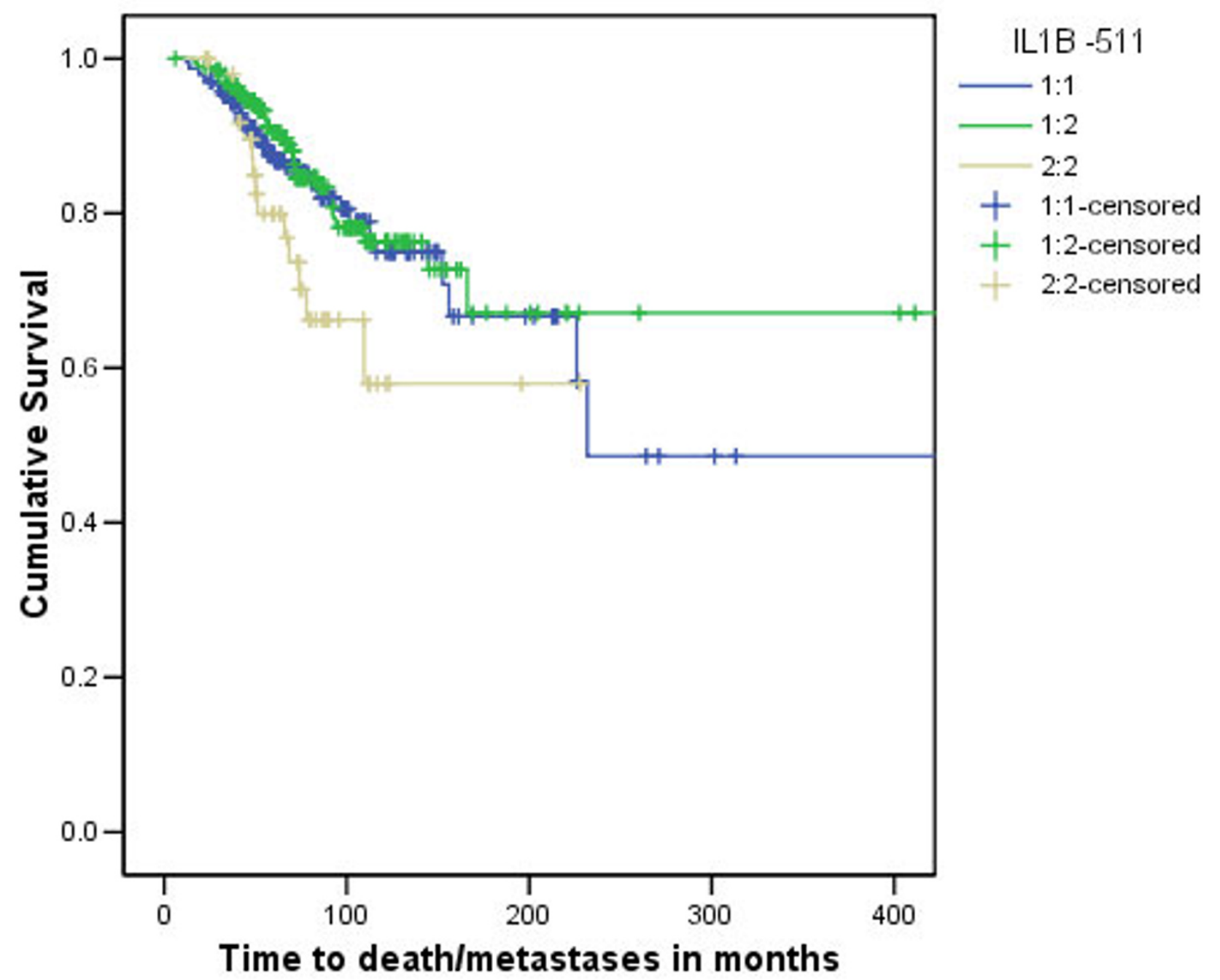

Figure 2

shows the time to death or metastases in invasive breast cancer for the genotypes of the ILIB -5 I I polymorphism. Log Rank test statistic $=5.07 ; \mathrm{df}=2 ; \mathrm{p}=0.08(\mathrm{n}=484)$. 


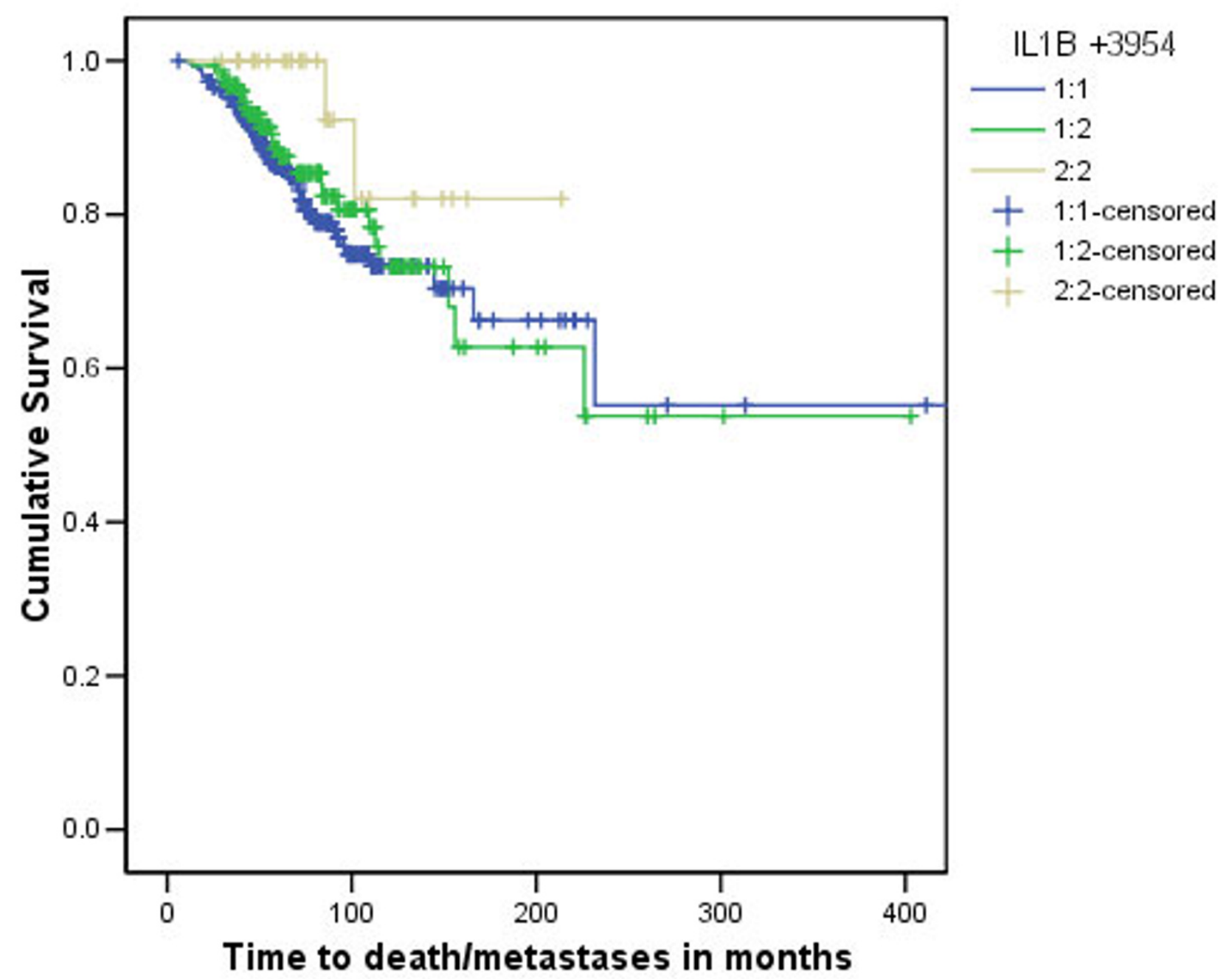

Figure 3

shows the time to death or metastases in invasive breast cancer for the genotypes of the ILIB +3954 polymorphism. Log Rank test statistic $=2.7 \mathrm{I} ; \mathrm{df}=2 ; \mathrm{p}=0.26(\mathrm{n}=479)$. 


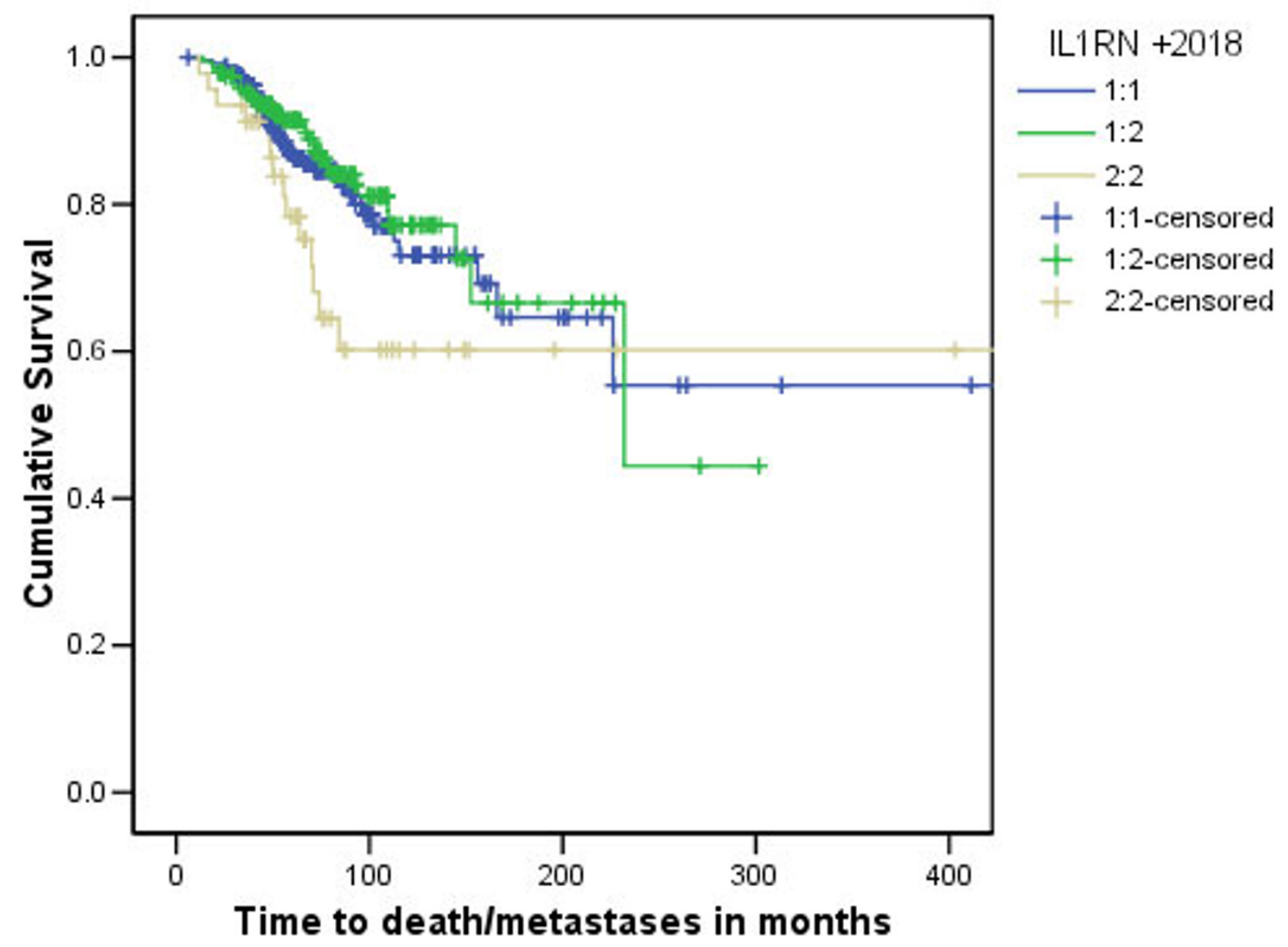

Figure 4

shows the time to death or metastases in invasive breast cancer for the genotypes of the ILIRN +20I8 polymorphism. Log Rank test statistic $=4.32 ; \mathrm{df}=2 ; \mathrm{p}=0.12(\mathrm{n}=48 \mathrm{I})$. 


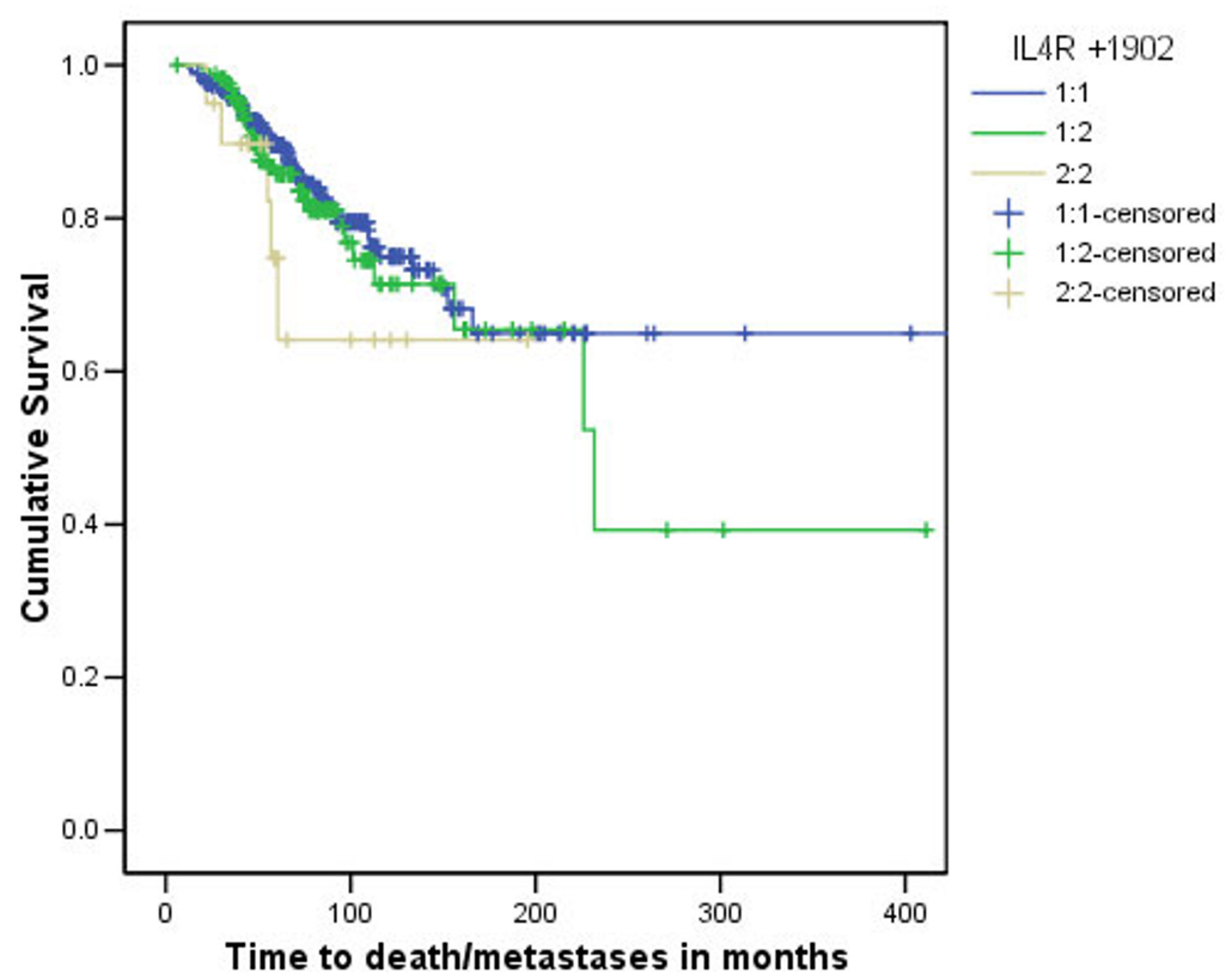

Figure 5

shows the time to death or metastases in invasive breast cancer for the genotypes of the IL4R + I902 polymorphism. Log Rank test statistic $=2.07 ; \mathrm{df}=2 ; \mathrm{p}=0.35(\mathrm{n}=528)$. 


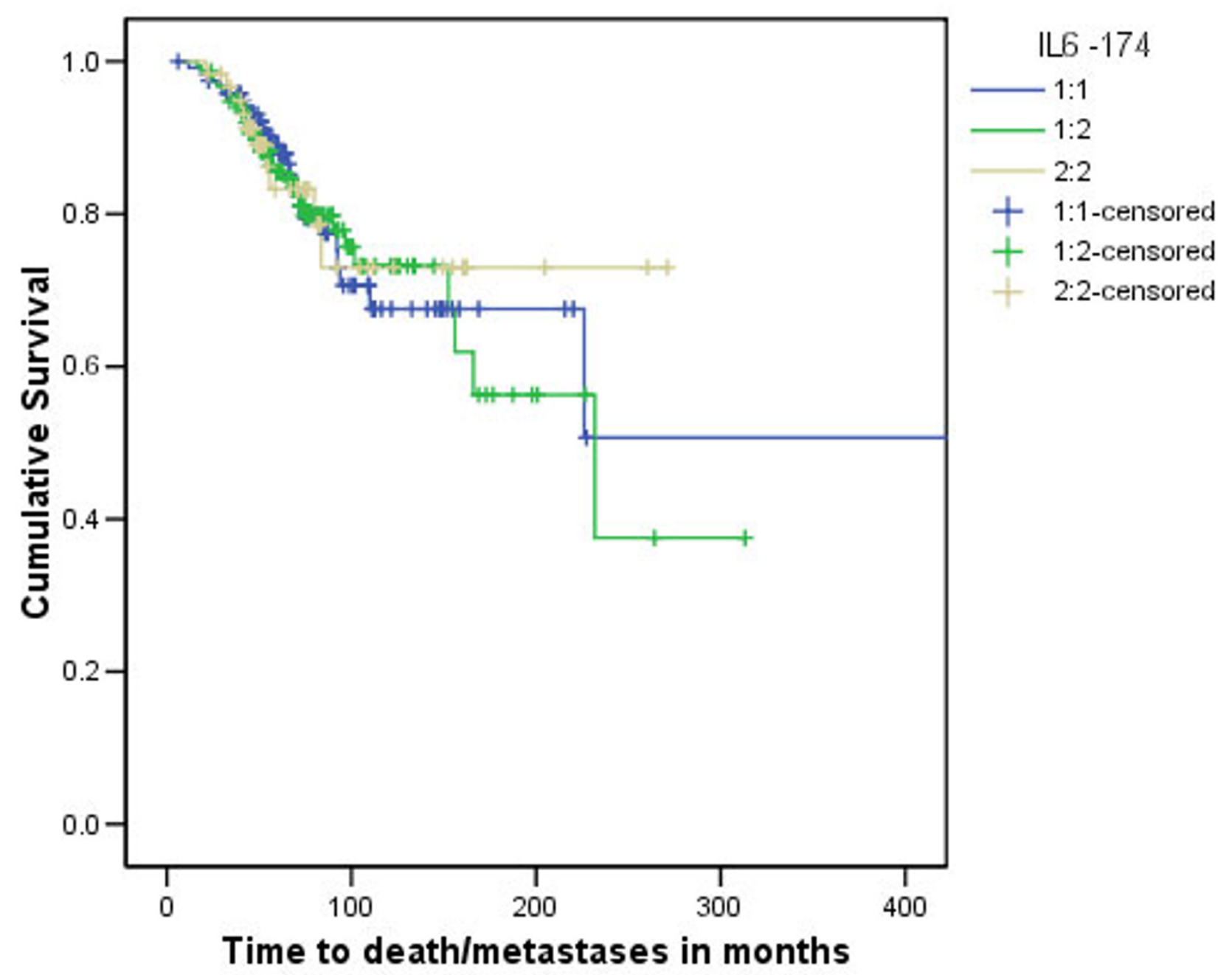

Figure 6

shows the time to death or metastases in invasive breast cancer for the genotypes of the IL6 - I74 polymorphism. Log Rank test statistic $=0.16 ; d f=2 ; p=0.92(n=333)$. 


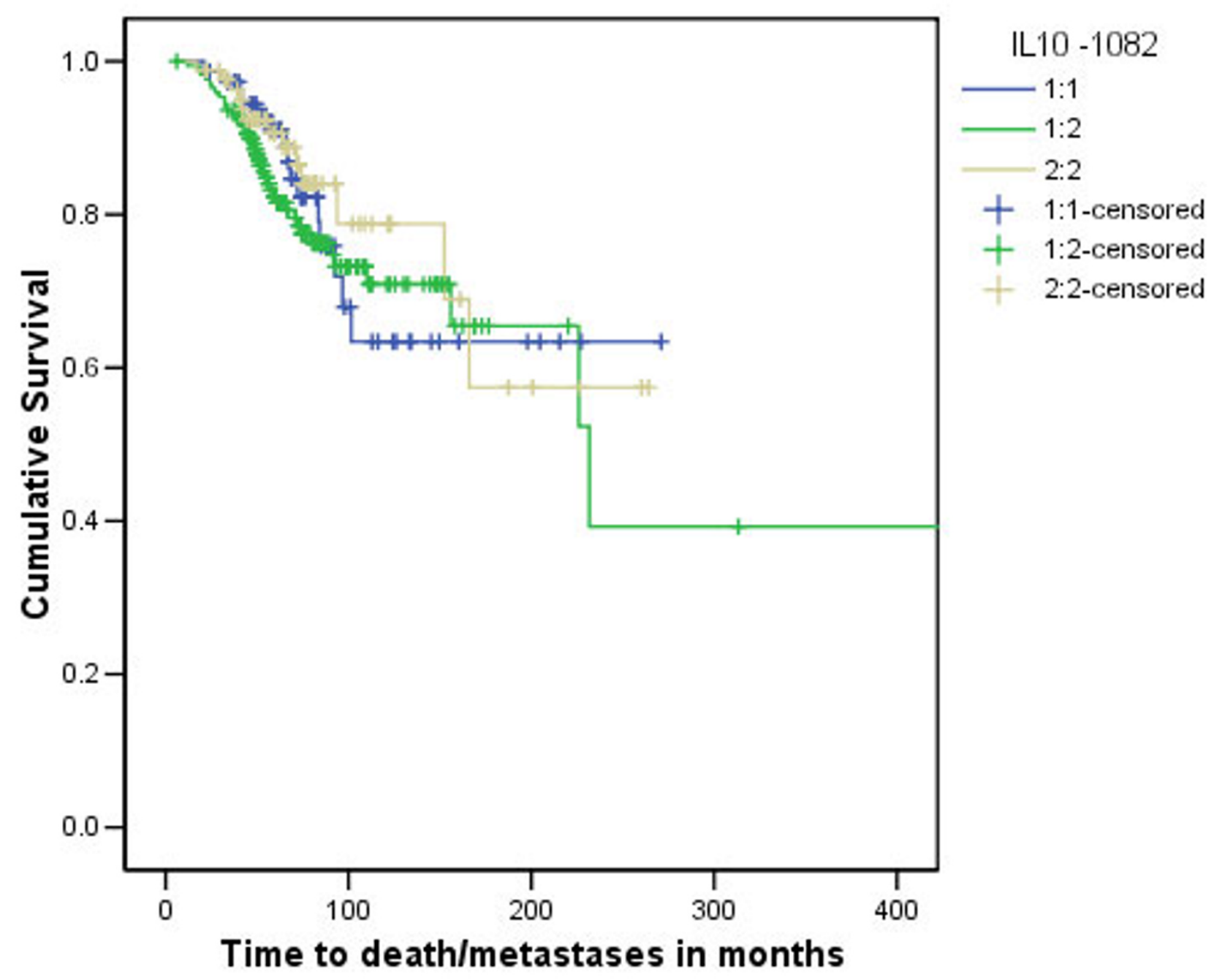

Figure 7

shows the time to death or metastases in invasive breast cancer for the genotypes of the ILI0 - I082 polymorphism. Log Rank test statistic $=1.34 ; \mathrm{df}=2 ; \mathrm{p}=0.5 \mathrm{I}(\mathrm{n}=332)$. 


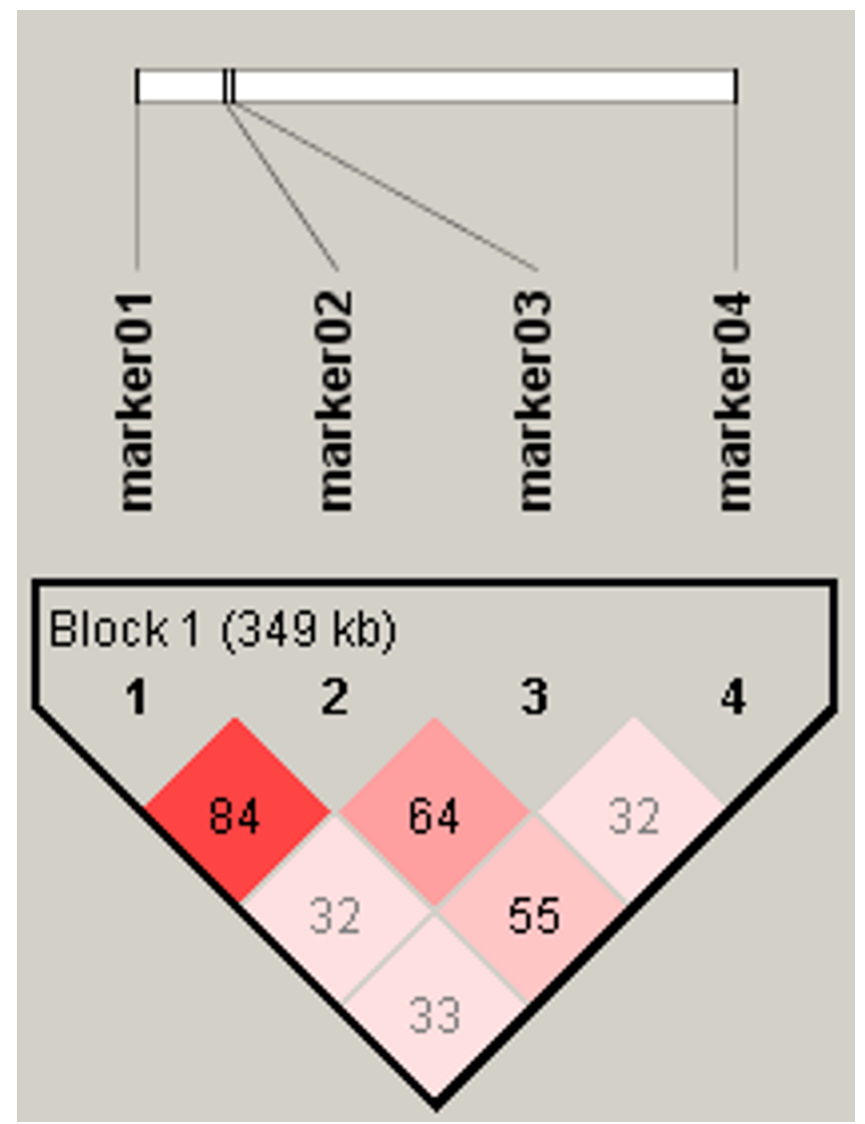

\section{Figure 8}

shows the linkage disequilibrium plot (obtained using Haploview) showing pairwise $D^{\prime}$ values (in percentage) between the four polymorphisms on chromosome $2 \mathrm{ql} 3$. The markers I, 2, 3 and 4 are IL IA +4845G $>$ T, ILIB +3954C>T, ILIB -5 I I $\mathrm{C}>\mathrm{T}$ and ILIRN $+2018 \mathrm{~T}>\mathrm{C}$ respectively.

Table 7: Probable frequencies of the common haplotypes in the interleukin-I gene cluster in breast cancer and screening control cohorts.

\begin{tabular}{lllll}
\hline Haplotype* & Frequency & Case, Control Ratios & Chi-square & P value \\
\hline GCCT & 0.330 & $471.5: 938.5,321.5: 674.5$ & 0.352 & 0.5529 \\
TTCT & 0.165 & $220.7: 1189.3,176.8: 819.2$ & 1.865 & 0.1720 \\
GCTC & 0.133 & $182.1: 1227.9,138.3: 857.7$ & 0.469 & 0.4934 \\
GCTT & 0.112 & $169.0: 1241.0,99.9: 896.1$ & 2.239 & 0.1346 \\
GCCC & 0.099 & $145.8: 1264.2,91.3: 904.7$ & 0.913 & 0.3392 \\
TCCT & 0.032 & $42.1: 1367.9,35.4: 960.6$ & 0.602 & 0.4376 \\
TCTT & 0.026 & $32.4: 1377.6,30.1: 965.9$ & 1.202 & 0.2729 \\
GTCT & 0.024 & $36.1: 1373.9,22.6: 973.4$ & 0.214 & 0.6440 \\
TTCC & 0.022 & $33.5: 1376.5,19.9: 976.1$ & 0.377 & 0.5394 \\
TTTT & 0.017 & $21.2: 1388.8,19.8: 976.2$ & 0.817 & 0.3661 \\
TCCC & 0.016 & $24.6: 1385.4,14.1: 981.9$ & 0.4 & 0.5271 \\
TCTC & 0.013 & $16.7: 1393.3,14.3: 981.7$ & 0.295 & 0.5873
\end{tabular}

\footnotetext{
* The haplotypes represent the four polymorphisms (ILIA +4845G > T, ILIB +3954C $>T$, ILIB -5 IIC $>T$ and ILIRN +20I8T>C) in that order.
} 
Table 8: Studies of the ILIB -5 I I C > T polymorphism in breast cancer.

\begin{tabular}{|c|c|c|c|c|c|c|}
\hline \multirow[t]{2}{*}{ Reference } & \multicolumn{2}{|c|}{ Numbers studied } & \multirow[t]{2}{*}{ Type of controls } & \multirow[t]{2}{*}{ Susceptibility } & \multirow[t]{2}{*}{ Severity } & \multirow[t]{2}{*}{ Ethnicity } \\
\hline & Cancer & Controls & & & & \\
\hline Smith KC et al, 2004 [57] & $14 \mid$ & 261 & $\begin{array}{l}\text { Bone marrow and solid organ donors - } \\
\text { male and female }\end{array}$ & No association & No association & mixed \\
\hline Hefler LA et al, 2005 [58] & 269 & 227 & $\begin{array}{l}\text { Women visiting outpatient dept for } \\
\text { various reasons }\end{array}$ & No association & No association & Caucasian \\
\hline Our study & 703 & 489 & $\begin{array}{l}\text { Women with normal mammograms } \\
\text { from screening population }\end{array}$ & No association & No association & British Caucasian \\
\hline
\end{tabular}

Table 9: Studies of the ILIB +3954 C $>$ T polymorphism in breast cancer.

\begin{tabular}{|c|c|c|c|c|c|c|}
\hline \multirow[t]{2}{*}{ Reference } & \multicolumn{2}{|c|}{ Numbers studied } & \multirow[t]{2}{*}{ Type of controls } & \multirow[t]{2}{*}{ Susceptibility } & \multirow[t]{2}{*}{ Severity } & \multirow[t]{2}{*}{ Ethnicity } \\
\hline & Cancer & Controls & & & & \\
\hline Hefler LA et al, 2005 [58] & 269 & 227 & $\begin{array}{l}\text { Women visiting outpatient dept for } \\
\text { various reasons }\end{array}$ & No association & No association & Caucasian \\
\hline Our study & 691 & 420 & $\begin{array}{l}\text { Women with normal mammograms } \\
\text { from screening population }\end{array}$ & No association & No association & British Caucasian \\
\hline
\end{tabular}

Table 10: Studies of the IL6 - I 74G $>$ C polymorphism in breast cancer.

\begin{tabular}{|c|c|c|c|c|c|c|}
\hline \multirow[t]{2}{*}{ Reference } & \multicolumn{2}{|c|}{ Numbers studied } & \multirow[t]{2}{*}{ Type of controls } & \multirow[t]{2}{*}{ Susceptibility } & \multirow[t]{2}{*}{ Severity } & \multirow[t]{2}{*}{ Ethnicity } \\
\hline & Cancer & Controls & & & & \\
\hline $\begin{array}{l}\text { Smith KC et al, } \\
2004 \text { [57] }\end{array}$ & 144 & 224 & $\begin{array}{l}\text { Bone marrow and solid organ } \\
\text { donors - male and female }\end{array}$ & No association & No association & mixed \\
\hline $\begin{array}{l}\text { Hefler LA et al, } \\
2005 \text { [58] }\end{array}$ & 269 & 227 & $\begin{array}{l}\text { Women visiting outpatient } \\
\text { dept for various reasons }\end{array}$ & $\begin{array}{l}\text { OR }=1.5(1.04- \\
2.3)^{*} \text { for GC vs. } \\
\text { GG OR = } 2(1.1- \\
3.6)^{*} \text { for CC vs. } \\
\text { GG }\end{array}$ & No association & Caucasian \\
\hline $\begin{array}{l}\text { Skerrett DL et al, } \\
2005 \text { [59] }\end{array}$ & 88 & 102 & Maternal cord blood samples & No association & No association & mixed \\
\hline $\begin{array}{l}\text { Saha A et al, } 2003 \\
\text { [60] }\end{array}$ & 26 & 95 & Unknown & No association & Not studied & Asian Indian \\
\hline $\begin{array}{l}\text { DeMichelle A et al, } \\
2003 \text { [6I] }\end{array}$ & 80 & 0 & - & Not studied & $\begin{array}{l}C \text { allele associated with } 4 \\
\text { year disease free survival ( } p \\
=0.02) \text { and overall survival } \\
(p=0.01) \text { in node positive } \\
\text { patients }\end{array}$ & mixed \\
\hline $\begin{array}{l}\text { lacopetta B et al, } \\
2004 \text { [62] }\end{array}$ & 256 & 0 & - & Not studied & $\begin{array}{l}C \text { allele associated with high } \\
\text { grade }(p=0.04) \text { and } C C \\
\text { genotype associated with } \\
\text { poor survival }(p=0.03)\end{array}$ & mixed \\
\hline Our study & 497 & 490 & $\begin{array}{l}\text { Women with normal } \\
\text { mammograms from screening } \\
\text { population }\end{array}$ & No association & No association & British Caucasian \\
\hline
\end{tabular}

OR: Odds Ratio 
Table I I: Studies of the ILI0 - I082G>A polymorphism in breast cancer.

\begin{tabular}{|c|c|c|c|c|c|c|}
\hline \multirow[t]{2}{*}{ Reference } & \multicolumn{2}{|c|}{ Numbers studied } & \multirow[t]{2}{*}{ Type of controls } & \multirow[t]{2}{*}{ Susceptibility } & \multirow[t]{2}{*}{ Severity } & \multirow[t]{2}{*}{ Ethnicity } \\
\hline & Cancer & Controls & & & & \\
\hline Smith KC et al, 2004 [57] & 129 & 223 & $\begin{array}{l}\text { Bone marrow and solid } \\
\text { organ donors - male and } \\
\text { female }\end{array}$ & No association & No association & Mixed \\
\hline $\begin{array}{l}\text { Giordani L et al, } 2003 \\
\text { [63] }\end{array}$ & 125 & 100 & $\begin{array}{l}\text { Female outpatients without } \\
\text { breast cancer }\end{array}$ & $\begin{array}{l}O R=0.58(0.32-1.07) \text { for } \\
A G \text { vs. } A A \text { OR }=0.38 \\
(0.14-0.99) \text { for } G G \text { vs. AA }\end{array}$ & Not studied & unknown \\
\hline $\begin{array}{l}\text { Skerrett DL et al, } 2005 \\
\text { [59] }\end{array}$ & 88 & 102 & $\begin{array}{l}\text { Maternal cord blood } \\
\text { samples }\end{array}$ & No association & No association & mixed \\
\hline Wu JM et al, 2005 [64] & 87 & 0 & - & Not studied & No association & mixed \\
\hline Our study & 497 & 498 & $\begin{array}{l}\text { Women with normal } \\
\text { mammograms from } \\
\text { screening population }\end{array}$ & No association & No association & British Caucasian \\
\hline
\end{tabular}

OR: Odds Ratio

\section{References}

I. Smyth MJ, Cretney E, Kershaw MH, Hayakawa Y: Cytokines in cancer immunity and immunotherapy. Immunol Rev 2004 202:275-293.

2. de Jong MM, Nolte IM, te Meerman GJ, van der Graaf WT, Oosterwijk JC, Kleibeuker JH, Schaapveld M, de Vries EG: Genes other than BRCAI and BRCA2 involved in breast cancer susceptibility. J Med Genet 2002, 39(4):225-242.

3. El-Omar EM, Rabkin CS, Gammon MD, Vaughan TL, Risch HA, Schoenberg JB, Stanford JL, Mayne ST, Goedert J, Blot WJ, Fraumeni JFJ Chow WH: Increased risk of noncardia gastric cancer associated with proinflammatory cytokine gene polymorphisms. Gastroenterology 2003, I 24(5): I I93-I201.

4. Lu W, Pan K, Zhang L, Lin D, Miao X, You W: Genetic polymorphisms of interleukin (IL)- I B, IL-I RN, IL-8, IL-I 0 and tumor necrosis factor \{alpha\} and risk of gastric cancer in a Chinese population. Carcinogenesis 2005, 26(3):63I-636.

5. Zambon CF, Basso D, Navaglia F, Belluco C, Falda A, Fogar P, Greco E, Gallo N, Rugge M, Di Mario F, Plebani M: Pro- and anti-inflammatory cytokines gene polymorphisms and Helicobacter pylori infection: interactions influence outcome. Cytokine 2005, 29(4): |4|-|52.

6. Nieters A, Yuan JM, Sun CL, Zhang ZQ, Stoehlmacher J, Govindarajan $S$, Yu MC: Effect of cytokine genotypes on the hepatitis B virus-hepatocellular carcinoma association. Cancer 2005 I 03(4):740-748.

7. Heneghan MA, Johnson PJ, Clare M, Ho S, Harrison PM, Donaldson PT: Frequency and nature of cytokine gene polymorphisms in hepatocellular carcinoma in Hong Kong Chinese. Int J Gastrointest Cancer 2003, 34(I): 19-26.

8. Campa D, Hung RJ, Mates D, Zaridze D, Szeszenia-Dabrowska N, Rudnai P, Lissowska J, Fabianova E, Bencko V, Foretova L, Janout V Boffetta P, Brennan P, Canzian F: Lack of association between polymorphisms in inflammatory genes and lung cancer risk. Cancer Epidemiol Biomarkers Prev 2005, I 4(2):538-539.

9. Burmester JK, Suarez BK, Lin JH, Jin CH, Miller RD, Zhang KQ, Salz man SA, Reding DJ, Catalona WJ: Analysis of candidate genes for prostate cancer. Hum Hered 2004, 57(4): I72-178.

10. Hefler LA, Ludwig E, Lebrecht A, Zeillinger R, Tong-Cacsire D, Koelb $\mathrm{H}$, Leodolter S, Tempfer CB: Polymorphisms of the interleukinI gene cluster and ovarian cancer. I Soc Gynecol Investig 2002, 9(6):386-390.

II. Pantschenko AG, Pushkar I, Anderson KH, Wang Y, Miller LJ, Kurtzman SH, Barrows G, Kreutzer DL: The interleukin-I family of cytokines and receptors in human breast cancer: implications for tumor progression. Int J Oncol 2003, 23(2):269-284.

12. Gooch JL, Lee AV, Yee D: Interleukin 4 inhibits growth and induces apoptosis in human breast cancer cells. Cancer Res 1998, 58( I 8):4199-4205.
I3. Obiri NI, Siegel JP, Varricchio F, Puri RK: Expression of high-affinity IL-4 receptors on human melanoma, ovarian and breast carcinoma cells. Clin Exp Immunol I 994, 95(I): I48-I55.

14. Benoy I, Salgado R, Colpaert C, Weytjens R, Vermeulen PB, Dirix LY: Serum interleukin 6, plasma VEGF, serum VEGF, and VEGF platelet load in breast cancer patients. Clin Breast Cancer 2002, 2(4):3।|-3|5.

15. Salgado R, Junius S, Benoy I, Van Dam P, Vermeulen P, Van Marck E, Huget $P$, Dirix LY: Circulating interleukin-6 predicts survival in patients with metastatic breast cancer. Int J Cancer 2003, I03(5):642-646.

16. Venetsanakos E, Beckman I, Bradley J, Skinner JM: High incidence of interleukin 10 mRNA but not interleukin 2 mRNA detected in human breast tumours. $\mathrm{Br} /$ Cancer 1997, 75(I2): 1826-1830.

17. Kundu N, Beaty TL, Jackson MJ, Fulton AM: Antimetastatic and antitumor activities of interleukin 10 in a murine model of breast cancer. J Natl Cancer Inst 1996, 88(8):536-54I.

18. Kumar S, Kishimoto H, Chua HL, Badve S, Miller KD, Bigsby RM, Nakshatri $\mathrm{H}$ : Interleukin-I alpha promotes tumor growth and cachexia in MCF-7 xenograft model of breast cancer. $\mathrm{Am} J$ Pathol 2003, I 63(6):2531-254I.

19. Speirs V, Kerin MI, Newton CJ, Walton DS, Green AR, Desai SB Atkin SL: Evidence for transcriptional activation of ERalpha by IL-Ibeta in breast cancer cells. Int I Oncol 1999, I5(6): | $25|-| 254$.

20. Suswam EA, Nabors LB, Huang Y, Yang X, King PH: IL-Ibeta induces stabilization of IL-8 mRNA in malignant breast cancer cells via the 3' untranslated region: Involvement of divergent RNA-binding factors HuR, KSRP and TIAR. Int J Cancer 2005, I I 3(6):911-919.

21. Volpert OV, Fong T, Koch AE, Peterson JD, Waltenbaugh C, Tepper RI, Bouck NP: Inhibition of angiogenesis by interleukin 4. J Exp Med 1998, I 88(6): 1039-1046.

22. van den Velden PA, Reitsma PH: Amino acid dimorphism in ILIA is detectable by PCR amplification. Hum Mol Genet 1993 , 2(I0): 1753

23. Kawaguchi $Y$, Tochimoto $A$, Ichikawa $N$, Harigai $M$, Hara M, Kotake S, Kitamura Y, Kamatani N: Association of IL I A gene polymorphisms with susceptibility to and severity of systemic sclerosis in the Japanese population. Arthritis Rheum 2003, 48(I): 186-192.

24. Berger P, McConnell JP, Nunn M, Kornman KS, Sorrell J, Stephenson $\mathrm{K}$, Duff GW: C-reactive protein levels are influenced by common IL-I gene variations. Cytokine 2002, I 7(4): |7|- I74.

25. Li QY, Zhao HS, Meng HX, Zhang L, Xu L, Chen ZB, Shi D, Feng XH, Zhu XL: Association analysis between interleukin-I family polymorphisms and generalized aggressive periodontitis in a Chinese population. J Periodontol 2004, 75( I 2): I 627-I635.

26. Eklund C, Jahan F, Pessi T, Lehtimaki T, Hurme M: Interleukin IB gene polymorphism is associated with baseline $C$-reactive 
protein levels in healthy individuals. Eur Cytokine Netw 2003 14(3):|68-17|.

27. Pociot F, Molvig J, Wogensen L, Worsaae H, Nerup J: A Taql polymorphism in the human interleukin-I beta (IL-I beta) gene correlates with IL-I beta secretion in vitro. Eur J Clin Invest 1992, 22(6):396-402.

28. Dziedzic T, Slowik A, Pera J, Szczudlik A: Interleukin I Beta Polymorphism (-5I I) and Risk of Stroke due to Small Vessel Disease. Cerebrovasc Dis 2005, 20(5):299-303.

29. Perri F, Piepoli A, Bonvicini C, Gentile A, Quitadamo M, Di Candia M, Cotugno R, Cattaneo F, Zagari MR, Ricciardiello L, Gennarelli M, Bazzoli F, Ranzani GN, Andriulli A: Cytokine gene polymorphisms in gastric cancer patients from two Italian areas at high and low cancer prevalence. Cytokine 2005, 30(5):293-302.

30. Zhang WH, Wang XL, Zhou J, An LZ, Xie XD: Association of interleukin-IB (IL-IB) gene polymorphisms with risk of gastric cancer in Chinese population. Cytokine 2005, 30(6):378-38I.

31. Ruzzo A, Graziano F, Pizzagalli F, Santini D, Battistelli V, Panunzi S, Canestrari E, Catalano V, Humar B, Ficarelli R, Bearzi I, Cascinu S, Naldi N, Testa E, Magnani M: Interleukin IB gene (IL-IB) and interleukin I receptor antagonist gene (IL-IRN) polymorphisms in Helicobacter pylori-negative gastric cancer of intestinal and diffuse histotype. Ann Oncol 2005, 16(6):887-892.

32. Hurme M, Santtila S: IL-I receptor antagonist (IL-IRa) plasma levels are co-ordinately regulated by both IL-IRa and ILI beta genes. Eur J Immunol I998, 28(8):2598-2602.

33. Santtila S, Savinainen K, Hurme M: Presence of the IL-IRA allele 2 (ILIRN*2) is associated with enhanced IL-I beta production in vitro. Scand J Immunol I998, 47(3): I95-198.

34. Hu Z, Shao M, Chen Y, Zhou J, Qian J, Xu L, Ma H, Wang X, Xu Y, $\mathrm{Lu} D$, Shen $\mathrm{H}$ : Allele 2 of the interleukin-I receptor antagonist gene (ILIRN*2) is associated with a decreased risk of primary lung cancer. Cancer Lett 2005.

35. Sehouli J, Mustea A, Koensgen D, Lichtenegger W: Interleukin-I receptor antagonist gene polymorphism in epithelial ovarian cancer. Cancer Epidemiol Biomarkers Prev 2003, I 2(I I Pt I): $1205-1208$

36. Mustea A, Sehouli J, Konsgen D, Stengel D, Sofroni D, Lichtenegger W: Interleukin I receptor antagonist (IL-IRA) polymorphism in women with cervical cancer. Anticancer Res 2003, 23(2A): $1099-1102$.

37. Gough MD, Ackroyd R, Majeed AW, Bird NC: Prediction of malignant potential in reflux disease: are cytokine polymorphisms important? Am J Gastroenterol 2005, 100(5):1012-1018.

38. Hershey GK, Friedrich MF, Esswein LA, Thomas ML, Chatila TA: The association of atopy with a gain-of-function mutation in the alpha subunit of the interleukin-4 receptor. N Engl J Med 1997, 337(24): $1720-1725$

39. Aithal GP, Day CP, Leathart J, Daly AK, Hudson M: Association of single nucleotide polymorphisms in the interleukin-4 gene and interleukin- 4 receptor gene with Crohn's disease in a British population. Genes Immun 200I, 2(I):44-47.

40. Cui T, Wang L, Wu J, Hu L, Xie J: Polymorphisms of IL-4, IL-4R alpha, and AICDA genes in adult allergic asthma. J Huazhong Univ Sci Technolog Med Sci 2003, 23(2): 134-137.

4I. Nakamura E, Megumi Y, Kobayashi T, Kamoto T, Ishitoya S, Terachi T, Tachibana M, Matsushiro $H$, Habuchi T, Kakehi $Y$, Ogawa $O$ Genetic polymorphisms of the interleukin-4 receptor alpha gene are associated with an increasing risk and a poor prognosis of sporadic renal cell carcinoma in a Japanese population. Clin Cancer Res 2002, 8(8):2620-2625.

42. Fishman D, Faulds G, Jeffery R, Mohamed-Ali V, Yudkin JS, Humphries $S$, Woo P: The effect of novel polymorphisms in the inter leukin-6 (IL-6) gene on IL-6 transcription and plasma IL-6 levels, and an association with systemic-onset juvenile chronic arthritis. J Clin Invest 1998, I02(7):1369-I376.

43. Ogilvie EM, Fife MS, Thompson SD, Twine N, Tsoras M, Moroldo M, Fisher SA, Lewis CM, Prieur AM, Glass DN, Woo P: The -I 74G allele of the interleukin-6 gene confers susceptibility to systemic arthritis in children: a multicenter study using simplex and multiplex juvenile idiopathic arthritis families. Arthritis Rheum 2003, 48(I I):3202-3206.

44. Georges JL, Loukaci V, Poirier O, Evans A, Luc G, Arveiler D, Ruidavets JB, Cambien F, Tiret L: Interleukin-6 gene polymorphisms and susceptibility to myocardial infarction: the ECTIM study.
Etude Cas-Temoin de I'Infarctus du Myocarde. I Mol Med 200I, 79(5-6):300-305

45. Humphries SE, Luong LA, Ogg MS, Hawe E, Miller GJ: The interleukin-6 - $174 \mathrm{G} / \mathrm{C}$ promoter polymorphism is associated with risk of coronary heart disease and systolic blood pressure in healthy men. Eur Heart J 200I, 22(24):2243-2252

46. Leibovici D, Grossman HB, Dinney CP, Millikan RE, Lerner S, Wang $Y, G u J$, Dong $Q, W u X$ : Polymorphisms in inflammation genes and bladder cancer: from initiation to recurrence, progression, and survival. J Clin Oncol 2005, 23(24):5746-5756

47. Landi S, Moreno V, Gioia-Patricola L, Guino E, Navarro M, de Oca J, Capella G, Canzian F: Association of common polymorphisms in inflammatory genes interleukin (IL)6, IL8, tumor necrosis factor alpha, NFKB I, and peroxisome proliferator-activated receptor gamma with colorectal cancer. Cancer Res 2003 , 63(13):3560-3566

48. Foster CB, Lehrnbecher T, Samuels S, Stein S, Mol F, Metcalf JA, Wyvill K, Steinberg SM, Kovacs ], Blauvelt A, Yarchoan R, Chanock S]: An IL6 promoter polymorphism is associated with a lifetime risk of development of Kaposi sarcoma in men infected with human immunodeficiency virus. Blood 2000, 96(7):2562-2567.

49. Turner DM, Williams DM, Sankaran D, Lazarus M, Sinnott PJ, Hutchinson IV: An investigation of polymorphism in the interleukin10 gene promoter. Eur J Immunogenet 1997, 24(1): I-8.

50. Fernandez L, Martinez A, Mendoza JL, Urcelay E, Fernandez-Arquero M, Garcia-Paredes J, Diaz-Rubio M, de la Concha EG: Interleukin- I0 polymorphisms in Spanish patients with IBD. Inflamm Bowel Dis 2005, II (8):739-743.

5I. Shin HD, Park BL, Kim LH, Jung JH, Kim JY, Yoon JH, Kim YJ, Lee HS Interleukin 10 haplotype associated with increased risk of hepatocellular carcinoma. Hum Mol Genet 2003, I 2(8):90I-906.

52. Alonso R, Suarez A, Castro P, Lacave AJ, Gutierrez C: Influence of interleukin- 10 genetic polymorphism on survival rates in melanoma patients with advanced disease. Melanoma Res 2005, I 5(I):53-60

53. Rafii S, O'Regan P, Xinarianos G, Azmy I, Stephenson T, Reed M, Meuth M, Thacker J, Cox A: A potential role for the XRCC2 $\mathrm{RI} \mathbf{8 8 H}$ polymorphic site in DNA-damage repair and breast cancer. Hum Mol Genet 2002, I I ( 2): | 433- | 438 .

54. Azmy IA, Balasubramanian SP, Wilson AG, Stephenson TJ, Cox A, Brown NJ, Reed MW: Role of tumour necrosis factor gene polymorphisms (-308 and -238$)$ in breast cancer susceptibility and severity. Breast Cancer Res 2004, 6(4):R395-400.

55. di Giovine F. S. CNJCACAGSJACADGW: Detection and population analysis of IL-I and TNF gene polymorphisms. In Cytokine Molecular Biology - A practical approach Edited by: Balkwill F. Oxford, Oxford University Press; 2000:21-46.

56. Barrett JC, Fry B, Maller J, Daly MJ: Haploview: analysis and visualization of LD and haplotype maps. Bioinformatics 2005, 2I(2):263-265

57. Smith KC, Bateman AC, Fussell HM, Howell WM: Cytokine gene polymorphisms and breast cancer susceptibility and prognosis. Eur J Immunogenet 2004, 3 I (4): I67-I73.

58. Hefler LA, Grimm C, Lantzsch T, Lampe D, Leodolter S, Koelb H, Heinze G, Reinthaller A, Tong-Cacsire D, Tempfer C, Zeillinger R: Interleukin-I and interleukin- 6 gene polymorphisms and the risk of breast cancer in caucasian women. Clin Cancer Res 2005, II (16):57|8-572I

59. Skerrett DL, Moore EM, Bernstein DS, Vahdat L: Cytokine genotype polymorphisms in breast carcinoma: associations of TGF-betal with relapse. Cancer lnvest 2005, 23(3):208-2।4.

60. Saha A, Bairwa NK, Ranjan A, Gupta V, Bamezai R: Two novel somatic mutations in the human interleukin 6 promoter region in a patient with sporadic breast cancer. Eur J Immunogenet 2003, 30(6):397-400.

6I. DeMichele A, Martin AM, Mick R, Gor P, Wray L, Klein-Cabral M, Athanasiadis G, Colligan T, Stadtmauer E, Weber B: Interleukin-6 I74G-->C polymorphism is associated with improved outcome in high-risk breast cancer. Cancer Res 2003, 63(22):805I-8056.

62. lacopetta B, Grieu F, Joseph D: The -174 G/C gene polymorphism in interleukin-6 is associated with an aggressive breast cancer phenotype. Br J Cancer 2004, 90(2):419-422.

63. Giordani L, Bruzzi P, Lasalandra C, Quaranta M, Schittulli F, Della Ragione $\mathrm{F}$, lolascon A: Association of breast cancer and poly- 
morphisms of interleukin- 10 and tumor necrosis factoralpha genes. Clin Chem 2003, 49(10): 1664-1667.

64. Wu JM, Bensen-Kennedy D, Miura Y, Thoburn CJ, Armstrong D, Vogelsang GB, Hess AD: The effects of interleukin 10 and interferon gamma cytokine gene polymorphisms on survival after autologous bone marrow transplantation for patients with breast cancer. Biol Blood Marrow Transplant 2005, I I(6):455-464.

65. Nozaki S, Sledge GW], Nakshatri H: Cancer cell-derived interleukin Ialpha contributes to autocrine and paracrine induction of pro-metastatic genes in breast cancer. Biochem Biophys Res Commun 2000, 275(I):60-62.

66. Miller LJ, Kurtzman SH, Anderson K, Wang Y, Stankus M, Renna M, Lindquist R, Barrows G, Kreutzer DL: Interleukin-I family expression in human breast cancer: interleukin-I receptor antagonist. Cancer Invest 2000, I 8(4):293-302.

67. Ito LS, Iwata H, Hamajima N, Saito T, Matsuo K, Mizutani M, Iwase T, Miura S, Okuma K, Inoue M, Hirose K, Tajima K: Significant reduction in breast cancer risk for Japanese women with interleukin IB -3 I CT/TT relative to CC genotype. Jpn J Clin Oncol 2002, 32(10):398-402.

68. Jin L, Yuan RQ, Fuchs A, Yao Y, Joseph A, Schwall R, Schnitt SJ, Guida A, Hastings HM, Andres J, Turkel G, Polverini PJ, Goldberg ID, Rosen EM: Expression of interleukin-Ibeta in human breast carcinoma. Cancer 1997, 80(3):42।-434.

69. Honma S, Shimodaira K, Shimizu Y, Tsuchiya N, Saito H, Yanaihara T, Okai $\mathrm{T}$ : The influence of inflammatory cytokines on estrogen production and cell proliferation in human breast cancer cells. Endocr J 2002, 49(3):37I-377.

70. Nicklin MJ, Barton JL, Nguyen M, FitzGerald MG, Duff GW, Kornman $\mathrm{K}$ : A sequence-based map of the nine genes of the human interleukin-I cluster. Genomics 2002, 79(5):718-725.

7I. Lindmark F, Zheng SL, Wiklund F, Balter KA, Sun J, Chang B, Hedelin M, Clark J, Johansson JE, Meyers DA, Adami HO, Isaacs W, Gronberg $\mathrm{H}, \mathrm{Xu}$ J: Interleukin-I receptor antagonist haplotype associated with prostate cancer risk. BrJ Cancer 2005, 93(4):493-497.

72. Kawakami K, Kawakami M, Husain SR, Puri RK: Effect of interleukin (IL)-4 cytotoxin on breast tumor growth after in vivo gene transfer of IL-4 receptor alpha chain. Clin Cancer Res 2003, 9(5): $1826-1836$.

73. Bugawan TL, Mirel DB, Valdes AM, Panelo A, Pozzilli P, Erlich HA: Association and interaction of the IL4R, IL4, and ILI 3 loci with type I diabetes among Filipinos. Am J Hum Genet 2003, 72(6): $|505-| 5 \mid 4$.

74. Berger FG: The interleukin- 6 gene: a susceptibility factor that may contribute to racial and ethnic disparities in breast cancer mortality. Breast Cancer Res Treat 2004, 88(3):28I-285.

75. Terry CF, Loukaci V, Green FR: Cooperative influence of genetic polymorphisms on interleukin 6 transcriptional regulation. J Biol Chem 2000, 275(24): $18138-18 \mid 44$.

76. Merendino RA, Gangemi S, Misefari A, Arena A, Capozza AB, Chillemi $S$, D'Ambrosio FP: Interleukin- 12 and interleukin- 10 production by mononuclear phagocytic cells from breast cancer patients. Immunol Lett 1999, 68(2-3):355-358.

77. Kozlowski L, Zakrzewska I, Tokajuk P, Wojtukiewicz MZ: Concentration of interleukin-6 (IL-6), interleukin-8 (IL-8) and interleukin-10 (IL-I0) in blood serum of breast cancer patients. Rocz Akad Med Bialymst 2003, 48:82-84.

78. Alamartine E, Berthoux P, Mariat C, Cambazard F, Berthoux F: Interleukin- 10 promoter polymorphisms and susceptibility to skin squamous cell carcinoma after renal transplantation. J Invest Dermatol 2003, I 20(I):99-103.

79. Langsenlehner U, Krippl P, Renner W, Yazdani-Biuki B, Eder T, Koppel H, Wascher TC, Paulweber B, Samonigg H: Interleukin- IO promoter polymorphism is associated with decreased breast cancer risk. Breast Cancer Res Treat 2005, 90(2): I I3-I I 5.

\section{Pre-publication history}

The pre-publication history for this paper can be accessed here:

\section{http://www.biomedcentral.com/1471-2407/6/188/pre} pub

\section{Publish with Bio Med Central and every scientist can read your work free of charge}

"BioMed Central will be the most significant development for disseminating the results of biomedical research in our lifetime. "

Sir Paul Nurse, Cancer Research UK

Your research papers will be:

- available free of charge to the entire biomedical community

- peer reviewed and published immediately upon acceptance

- cited in PubMed and archived on PubMed Central

- yours - you keep the copyright

Submit your manuscript here:

http://www.biomedcentral.com/info/publishing_adv.asp
BiolMedcentral 